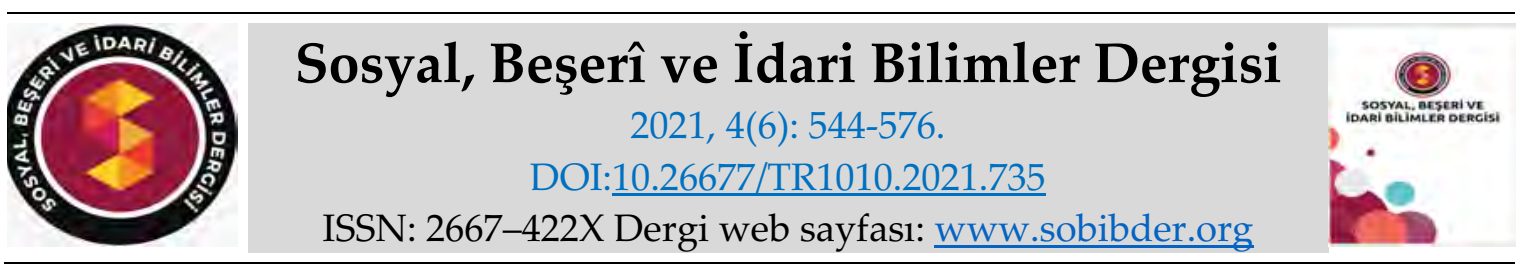

KAVRAMSAL MAKALE

\title{
Uluslararası Seyahat ve Turizm Rekabetçilik Endeksi Kapsamında Türkiye'nin Güçlü ve Zayıf Yönlerinin Değerlendirilmesi
}

\author{
Doç. Dr. Ramazan GÖRAL, Selçuk Üniversitesi, Beyşehir Ali Akkanat Turizm Fakültesi, Konya, \\ e-posta: trgoral28@hotmail.com \\ ORCID: https://orcid.org/0000-0002-9826-042X
}

Öğr. Gör. Murat YURTLU, İskenderun Teknik Üniversitesi, Turizm Fakültesi, Hatay, e-posta: murat.yurtlu@iste.edu.tr ORCID: https://orcid.org/0000-0002-0947-8401

\begin{abstract}
Öz
Uluslararası rekabette yaşanan artış, turizm hedeflerini gerçekleştirmek isteyen destinasyonlar için rekabetçi güçlerin analizini, destinasyonu bekleyen fırsat ve tehditleri değerlendirmeyi zorunlu kılmaktadır. Alanyazında destinasyon rekabetçiliğinde önemli olan faktörlere yönelik çeşitli çalışmalar bulunmaktadır. Destinasyon rekabetçiliği konusunda yapılan en kapsamlı çalı̧maların başında Dünya Ekonomik Forumu (WEF) tarafından oluşturulan Seyahat ve Turizm Rekabetçilik Endeksi (TTCI) raporu gelmektedir. Bu çalışmanın amacı, Türkiye'nin turizmdeki uluslararası rekabetçi konumunu TTCI 2019 raporu verilerini esas alarak değerlendirmek ve mevcut görünümünü ortaya koyarak rekabetçi konumuna etki eden olumlu ve olumsuz faktörleri belirlemektir. Raporda 140 ülkeye ilişkin veriler yer almakta ve ülkeler, rapordaki dört ana faktör, 14 alt faktör ve alt faktörleri oluşturan toplam 90 gösterge üzerinden değerlendirilerek sıralanmaktadır. Çalışmada raporda yer alan 140 ülke 5'li gruplandırılarak Türkiye'nin rekabetçi konumu, ilgili gruplandırmaya yönelik değerlendirilmiştir. Buna göre; 1. Grup = Çok iyi (1-30. sırada bulunmak), 2. Grup = İyi (31-60. sirada bulunmak), 3. Grup = Orta (61-90. sirada bulunmak), 4. Grup $=$ Zayıf (91-120. sırada bulunmak) ve 5. Grup = Çok zayıf (121-140. sırada bulunmak) biçiminde analiz yapılmıştır ve 140 ülke endekste yer alan her bir rekabetçilik faktörleri sıralamasına göre $5^{\prime} l i$ Gruplandırılmış Seri şeklinde düzenlenmiştir. Araştırmanın bulguları kapsamında Türkiye'nin Doğal ve Kültürel Kaynaklar açısından "çok iyi", Altyapı ile Turizm Politikaları ve Koşulların Etkinleştirilmesi bakımından "iyi" bir sınıflamada yer aldığı belirlenmiştir. Dolayısıyla bu faktörler açısından turizm rekabetçiliğinde Türkiye'nin Güçlü olduğu değerlendirilebilir. Buna karşın Çevresel Faktörler açısından "orta" düzeyde ve gerilemekte olan bir görünüme sahip olduğu gözlenmiştir.
\end{abstract}

Anahtar Kelimeler: Destinasyon Rekabetçiliği, Rekabetçi Üstünlük, Dünya Ekonomik Forumu.

Makale Gönderme Tarihi: 01.04.2021

Makale Kabul Tarihi: 03.06.2021

\section{Önerilen Atıf:}

Göral, R. ve Yurtlu, M. (2021). Uluslararası Seyahat ve Turizm Rekabetçilik Endeksi Kapsamında Türkiye' nin Güçlü ve Zayıf Yönlerinin Değerlendirilmesi, Sosyal, Beşeri ve İdari Bilimler Dergisi, 4(6): 544-576. (c) 2021 Sosyal, Beşerî ve İdari Bilimler Dergisi. 


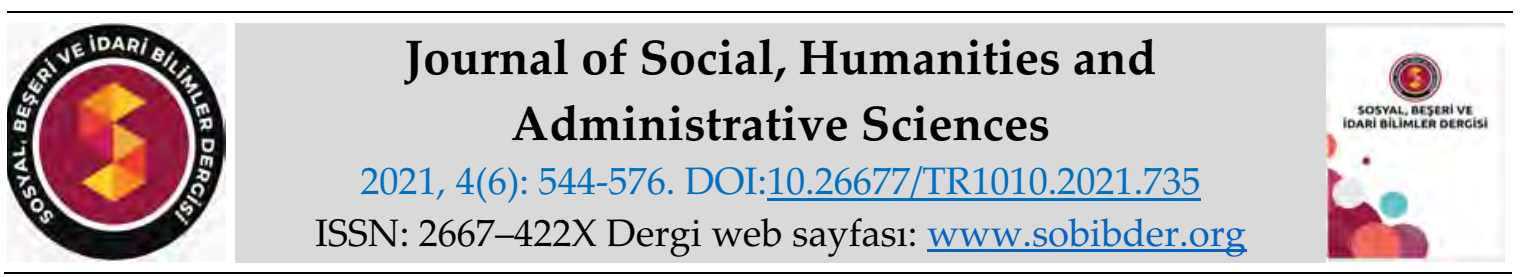

CONCEPTUAL PAPER

\title{
International Travel and Tourism Competitiveness Index: Evaluation of Turkey's Strengths and Weaknesses
}

Associate Prof. Dr. Ramazan GÖRAL, Selçuk University, Beyşehir Ali Akkanat Faculty of Tourism, Konya, e-mail: trgoral28@hotmail.com

ORCID: https://orcid.org/0000-0002-9826-042X

Lecturer Murat YURTLU, İskenderun Technical University, Faculty of Tourism, Hatay, e-mail: murat.yurtlu@iste.edu.tr

ORCID: https://orcid.org/0000-0002-0947-8401

\begin{abstract}
The increase in international competition necessitates the analysis of competitive forces and the evaluation of opportunities and threats awaiting the destination for destinations that want to achieve their tourism goals. In the literature, there are studies on factors that are important in destination competitiveness. One of the most comprehensive studies on destination competitiveness is the Travel and Tourism Competitiveness Index (TTCI) report created by the World Economic Forum (WEF). The purpose of this study is to evaluate the international competitive position of Turkey in tourism on the basis of TTCI 2019 report data and to determine the positive and negative factors that affect its competitive position by revealing its current appearance. The report includes data for 140 countries and countries are ranked by evaluating four main factors, 14 sub-factors and a total of 90 indicators that make up the sub-factors. In the study, 140 countries in the report were grouped in 5 and the competitive position of Turkey was evaluated for the related grouping. According to this; Group 1 = Very good (ranking 1-30), Group 2 = Good (ranking 31-60), Group 3 = Medium (ranking 61-90), Group 4 = Poor (91 Ranking -120) and Group 5 = Very poor (ranking 121-140) and 140 countries are arranged in 5-Group Grouped Series according to the order of competitiveness factors in the index. Within the scope of the findings of the research, it has been determined that Turkey is "very good" in terms of Natural and Cultural Resources and "good" in terms of Infrastructure and Tourism Policies and Conditions. Therefore, in terms of these factors, it can be evaluated that Turkey is strong in tourism competitiveness. On the other hand, it has been observed that it has a "medium" and declining appearance in terms of Environmental Factors.
\end{abstract}

Keywords: Destination Competitiveness, Competitive Advantage, World Economic Forum (WEF)

Received: 01.04 .2021

Accepted: 03.06.2021

Suggested Citation:

Göral, R. and Yurtlu, M. (2021). International Travel and Tourism Competitiveness Index: Evaluation of Turkey's Strengths and Weaknesses, Journal of Social, Humanities and Administrative Sciences, 4(6): 544-576. (C) 2021 Sosyal, Beşerî ve İdari Bilimler Dergisi. 


\section{Gíriş}

Turizm endüstrisi krizlere karşı kırılgan bir yapıya sahip olmasına rağmen özellikle 1990'lı yıllardan itibaren sürekli gelişmekte olan bir endüstri konumundadır ve $\% 3$ ortalama ile büyüyen performansı dünyanın en hızlı gelişen endüstrilerinden biri haline gelmesini sağlamıştır. Dünya geneli gibi Türkiye turizmi de hızlı bir gelişim göstererek dünya turizm gelişim ortalamasının iki katına varan bir görünüm sergilemiştir (Alaeddinoğlu ve Rol, 2020:238). Dünya Turizm Örgütü (UNWTO) 2019 raporuna göre, uluslararası turist sayısı 2019 yılında \%4 büyüme ile 1,5 milyar seviyesine ulaşmıştır (UNWTO, 2020). Kültür ve Turizm Bakanlığ 2019 verilerine göre ise 2019 yılında Türkiye turizmi, turist varışlarında bir önceki yıla göre \%12'lik bir artışla toplam 51,7 milyon turist sayısına ve turizm gelirlerinde \%17'lik bir artışla 34,5 milyar \$ gelir seviyesine çıkmıştır. İlgili turizm verilerine göre Türkiye'de turistlerin \%63'ü yabanc1, \%37'si ise yerli turist şeklindedir. Konaklama istatistiklerinde yaklaşık olarak 81 milyon tesise varış ve 211 milyon geceleme gerçekleşmiştir (T.C. Kültür ve Turizm Bakanlığı, 2020). Turizm, Türkiye'nin GSYİH'sında, ödemeler dengesinde ve işsizlik sorunlarının çözümünde son derece önemlidir. Dünya Seyahat ve Turizm Konseyi (WTTC) raporuna göre 2019 yllında Türkiye'de turizm endüstrisinin genel ekonomik katkıları; GSYIHH içinde \%11,3, istihdam içinde $\% 9,4$ ve toplam ihracat içinde \%17,5 seviyelerine ulaşmıştır (WTTC, 2020). Bu oranlar turizm endüstrisinin Türkiye ekonomisi için ne denli önemli olduğunu göstermektedir.

Covid-19 salgını, özellikle 2020 yılının ilk çeyreğinden itibaren etki alanını genişletmiş, dünya genelinde ekonomik, sosyal, fiziksel değişim ve gelişmeleri beraberinde getiren farklı dinamiklere sahip bir sürecin oluşmasına ve ülkelerin rekabet güçlerine ilişkin dengelerin değişebileceğine yönelik görüşlerin ortaya çımasına neden olmuştur (Okur, 2020:321). Bu sürecin yarattığı etkiler bakımından dünya genelinde en fazla turizm endüstrisini etkilediği görülmektedir. İlk kısıtlamalara tabii olan ve yine ilk serbestleşmeler kapsamında değerlendirilmekte olan turizm endüstrisinde destinasyonların salgına ilişkin oluşturdukları sağlık stratejileri ve altyapıları turistler tarafından destinasyon seçiminde önemli unsurlar haline gelmiştir (Dalkıran ve Bayrak, 2020:222). Dünya Turizm Örgütü'nün Ocak 2021'de yayınladığ 2020 yılının gerçekleşen uluslararası turist varışları sonuç raporuna göre, 2020 yılında turist sayısında 2019 yılıyla karşılaştırıldığında \%74'lük bir düşüş yaşanmıştır (UNWTO, 2021). Türkiye turizm endüstrisinde 2020 yılı verileri incelendiğinde ise toplam ziyaretçi sayısı \% 69 azalarak yaklaşık 15 milyon ziyaretçi şeklinde gerçekleşmiştir. Salgın nedeniyle Türkiye'nin turizm gelirlerinde $\%$ 65,1'lik bir düşüş olmuştur ve buna bağlı olarak turizm geliri 12,1 milyar \$’lara düşmüştür (T.C. Kültür ve Turizm Bakanlığı, 2021). Bununla birlikte Türkiye'de salgının başlarından itibaren çevik ve ivedi uygulanan sağlık politikalarının bir sonucu olarak dünya geneli ziyaretçi trafiği ortalamasından \% 6'lık bir oranda daha iyi bir 2020 yılı geçirdiği ve turist başı ortalama harcama oranlarında \% 14'ün üzerinde bir artış yakaladığı görülmektedir. UNWTO'nun genişletilmiş 2021-2024 senaryoları, 2021'in ikinci yarısında uluslararası turizmde bir toparlanmaya işaret etmektedir. Bununla birlikte, uluslararası gelişler açısından 2019 seviyelerine dönüşün 2,5 ila 4 yıl sürebileceği öngörülmektedir (UNWTO, 2021). Bu süreçte Türkiye, turizm gelirlerinde yaşanan kayıplarını en aza indirgemede rekabet gücünü korumaya yönelik sürdürülebilir faaliyet ve uygulamaları kısa sürede hayata geçirmiştir (KMPG Türkiye, 2021).

Turizmin yarattığı olumlu ekonomik etkilerden dolayı günümüzde ülkelerin bu ekonomik etkiyi sürekli kılmak adına kıyasıya bir rekabete girdikleri gözlenmektedir (Aydemir vd., 2014:1). Buna bağlı olarak ülkeler, turizmde rekabet gücünü arttırmada önemli olduğunu düşündükleri kaynakları sürdürülebilir olarak ortaya çıkarma çabası içine girmişlerdir (Fedajev vd., 2019). Destinasyonlar arası rekabet gücünde sürdürülebilir olmak ekonomik ve ekolojik sürdürülebilirliğin yanında kültürel, sosyal ve politik olarak da sürdürülebilirliği 
gerektirmektedir (Ritchie ve Crouch, 2003). Turizmin yerelde olumlu ekonomik ve sosyal katkılarına bağlı olarak uluslararası destinasyonlar arasında pazar rekabeti artmakta ve pazarlama çabaları önem kazanmaktadır. Rekabet üstünlügüunde destinasyonların rekabetçi güçlerinin ortaya çıkartılması, fırsatların ve tehditlerin değerlendirilmesi gerekmektedir (Çivi vd., 2008:18). Uluslararası rekabette her geçen gün yaşanan artışla birlikte turizmin belirlenen hedeflere ulaşması sağlanmalıdır. Hedeflere yönelik etkin stratejiler geliştirilebilmesi için mevcut durum analizlerinin ortaya çıkarılması gerekmektedir (Göral, 2017:142). Dünya Ekonomik Forumu (WEF)'nun 2007 yılından bu yana her iki yılda bir ve tek yıllarda (..., 2015, 2017, 2019 gibi) yayınladığ 1 Seyahat ve Turizm Rekabetçilik Endeksi (TTCI) raporu ülkelerin mevcut rekabet gücünü analiz etmede önemli veriler sunmaktadır.

Turizm endüstrisinin ekonomik, kültürel, çevresel ve siyasal unsurlar gibi çok sayıda faktörden etkilenmesi rekabet gücünün belirlenebilmesini zorlaştırmaktadır. Bu sebeple turizm destinasyonlarının doğrudan rekabetçiliğini ölçmede birçok model ve endeks geliştirilmiştir. Destinasyon rekabetçiliği konusunda en kapsamlı modeller Ritchie ve Crouch tarafından oluşturulan "Kavramsal Rekabet Modeli", Dwyer ve Kim'in ortaya koyduğu "Bütünleştirilmiş Rekabet Modeli" ve WEF'in TTCI endeksidir (Ritchie ve Crouch, 2003; Dwyer ve Kim, 2003; Pike ve Page, 2014:209; Burnaz ve Ayyıldız, 2018:239). Alanyazında TTCI raporunda yer alan faktör ve göstergelerin ölçüt alınarak Türkiye'nin incelendiği çeşitli araştırmalar bulunmaktadır. 2013 yılı raporunda 14 alt faktörün incelenerek Türkiye ve Avrupa'nın kıyaslama yoluyla değerlendirildiği (Aydemir vd., 2014), 2015 yılı raporundaki 14 alt faktörün tümünde Türkiye'nin kapsamlı bir biçimde değerlendirildiği (Göral, 2017), 2019 yılı raporunda Türkiye'yi de kapsamına alan Akdeniz turizm destinasyonlarının 12 gösterge ile değerlendirildiği (Manap Davras, 2020) çalışmalar yer almaktadır. Bu çalışmalardan Göral'ın 2015 yılı verileriyle yaptığı çalışması Türkiye'yi odak alarak TTCI faktörleri bazında detaylıca inceleyen en kapsamlı araştırmadır. Ayrıca 2019 yılı TTCI raporundaki faktörlerin tümünün ele alınarak Türkiye'nin rekabet gücünü ortaya koymaya yönelik herhangi bir araştırmaya rastlanılmamıştır. Bu noktada çalışmanın alanyazına katkı sağlayacağı öngörülmektedir. Bu çalışmanın amacı, Türkiye'nin uluslararası turizmdeki rekabetçi konumunu TTCI 2019 raporu verileri ışığında analiz ederek mevcut görünümünü ortaya çıkarmak ve rekabetçi konumuna etki yapan olumlu ve olumsuz faktörleri irdelemektir. Ayrıca araştırmanın diğer bir amacı; 2015, 2017 ve 2019 yıllarında yayınlanan rapor verileri doğrultusunda Türkiye'nin rekabetçi faktörler bağlamında durumunu analiz etmektir ve dolayısıyla bulgular, raporda yer alan verilerle sinırlıdır.

\section{KAVRAMSAL ÇERÇEVE}

\section{Destinasyon Rekabetçiliği ve TTCI Raporlarına Yönelik Araştırmalar}

Destinasyonların turizmdeki başarısı rekabetçilik güçlerine bağlıdır (Hovinen, 2002:210). "Destinasyon Rekabetçiliği", bir destinasyonun destinasyonlar arasındaki kıyaslamalarda turistlerce önemli görülen turizm deneyimini daha üstün bir performans ile sunabilme yeteneği biçiminde tanımlanmıştır (Dwyer ve Kim, 2003:374). Dupeyras ve MacCallum ise (2013) kavramı turizm rekabetçiliği olarak ele almışlar, destinasyonda ikamet eden ve etmeyenler dahil olmak üzere destinasyonun sahip olduğu çekiciliklerin yenilikçi, cazip ve kaliteli hizmetlerle bütünleşerek hem yerel hem de uluslararası turizm pazarlarında üstün pazar payı oluşturma becerisi şeklinde ifade etmişlerdir.

Destinasyon rekabetçiliği, 1990'lı yıllardan itibaren turizm araştırmacıları arasında artan bir ilgi alanı haline dönüşmüştür. Artan bu ilgiyle birlikte destinasyon rekabetçiliğine ilişkin araştırmalarda önemli bir artış gözlemlenmektedir. Araştırma konularına ilişkin olarak bu 
araştırmalardan bazıları; destinasyonlarda stratejik yönetim (Jamal ve Getz, 1996), destinasyonların yönetim sistemleri (Ankomah vd., 1996), destinasyonlarda konumlandırma (Chako, 1997), destinasyon imajı (Kozak ve Rimmington, 1999), destinasyon çevresi ve kalite yönetimi (Hassan, 2000), destinasyonlar arası fiyat rekabeti (Dwyer vd., 2000), destinasyonların pazarlaması (Buhalis, 2000), destinasyonlarda doğa temelli turizm (Huybers ve Bennett, 2003) şeklindedir. Bununla birlikte bazı araştırmaların ulusal, uluslararası veya seçili destinasyonlar düzeyinde yapıldığı görülmektedir. Bu destinasyonlar; iki ve daha fazla Akdeniz turizm destinasyonları (Baloglu ve McCleary, 1999; Kozak, 2002; Bahar ve Kozak, 2005; Marti ve Puertas, 2017), Yunanistan (Papatheodorou, 2002; Patsouratis vd., 2005), Güney Kore (Kim vd., 2003), Hong Kong (Enright ve Newton, 2004), Asya Pasifik ülkeleri (Enright ve Newton, 2005), Slovenya (Omerzel, 2006; Armenski vd., 2011), Romanya ve Bulgaristan (Croitoru, 2011) şeklindedir.

Destinasyon rekabetçiliğinde belirlenmiş alanlara özgü yapılan yukarıdaki örnek araştırmalar, destinasyon rekabet gücü konusunda literatüre önemli katkılar sunmakla birlikte destinasyon ya da çalışma konusuyla sınırlı olan araştırmalardır. Bu sebeple alanyazında belirli nitelikteki bölgelerin haricinde genele ilişkin destinasyon rekabetçiliğinde çeşitli araştırma teorileri ve modelleri geliştirmeye yönelik üçüncü bir yaklaşımdan da söz etmek mümkündür (Crouch, 2011). Bu doğrultuda destinasyon rekabetçiliği konularında çeşitli modeller oluşturularak yapılan farklı araştırmalar bulunmaktadır (Heath ve Wall, 1992; Crouch ve Ritchie, 1999; Dwyer ve Kim, 2003; Gursoy ve Kendall, 2004; Bãlan vd., 2009; Dupeyras ve MacCallum, 2013). Bu araştırmalardan Dwyer ve Kim 2003 yılında ulusal ve firmalar arası rekabet teorilerini kapsamına alan bir rekabetçilik modeli geliştirmişlerdir. Bu modeli oluşturan temel unsurlardan biri "kaynaklar"dır. Kaynaklar, kültürel ve doğal kaynaklar "bağışlanmış kaynaklar", altyapı, alışveriş, özel etkinlikler ile benzerleri "oluşturulmuş kaynaklar" ve ulaşılabilirlik, hizmet kalitesi gibi "destekleyici kaynaklar"dan oluşmaktadır. Bu modeli oluşturan ikinci temel unsur ise "destinasyon yönetimi"dir. Crouch ve Ritchie'nin yaptığı araştırmada ise destinasyonlar arası karşılaştırmalarda rekabet avantajlarına dayalı teorilerin yanında destinasyon rekabetçiliğinde fark yaratıcı özelliklere ilişkin kavramsal bir model geliştirilmiştir.

Destinasyon rekabetçiliğini etkileyen faktörleri ortaya koyan bir diğer çalışma, Dünya Ekonomik Forumu (WEF)'nun ilk kez 2007 yılında geliştirdiği ve son versiyonu 2019 yılında yayınlanan Seyahat ve Turizm Rekabetçilik Endeksi (TTCI) modeli, uluslararası turizm rekabetini ölçme ve değerlendirmeye ilişkin faktörlerin ele alındığı en kapsamlı çalışmalardan biridir (Akkuş, 2018:643). Rapor ilk yayınlandığı 2007 yılından itibaren araştırmacıların ilgisini çekmiştir. TTCI verilerine yönelik ilk araştırma Crouch tarafından 2007 yılında yapılmıştır. Araştırmada raporun içeriği, yapısı, metodolojisi, yararları incelenmiş ve raporun geliştirilmesine yönelik öneriler geliştirilmiştir. TTCI raporlarına ilişkin yapılan araştırma konuları, raporu oluşturan tüm faktörlerin ele alınarak belirli bir ülkenin rekabet gücünü ortaya çıkarmaya yönelik olduğu gibi belirli destinasyonların rakip veya sıralamalarda önde olan destinasyonlarla kıyaslanmasına yönelik olan araştırmalar şeklindedir. Belirlenmiş bir ülkenin rekabetçiliğine yönelik olarak Bello ve arkadaşları (2014) Nijerya'nın rekabetçi durumunu ortaya koymak amacıyla TTCI 2013 verilerinden yararlanmışlardır. Araştırmada raporda yer alan 140 ülke sıralamalarına göre 5'li gruplarda kategorize edilerek (1-30 arası mükemmel, 31-60 arası iyi, 61-90 arası orta, 91-120 arası kötü ve 121-140 arası çok kötü) raporu oluşturan her bir faktör ve bu faktörlerin alt faktörleri kapsamlı bir biçimde ele alınmış ve Nijerya'nın mevcut rekabetçi durumu irdelenmiştir. Yine aynı biçimde Göral (2017), TTCI 2015 verilerini baz alarak Türkiye'nin rekabetçi gücünü raporu oluşturan tüm faktörler kapsamında detaylı bir biçimde ortaya koymuştur. Araştırmada Türkiye'nin turizm rekabet gücünün kültürel kaynaklar ve altyapı faktörleri açısından iyi bir durumda olduğu belirlenmiştir. Buna karşın işletmecilik faaliyetleri için gerekli olan düzenlemelere yönelik olan çevresel faktörlerin yeterli seviyede olmadığı tespit edilmiştir. Ayrıca 
politika ve koşulların etkinleştirilmesi faktörünün turizm yatırımlarını teşvik edici bir seviyede olmadığı belirlenmiştir.

TTCI raporlarının belirli bir destinasyonun rakip destinasyonları ile kıyaslamasına yönelik olarak Aydemir ve arkadaşları (2014) Türkiye'nin Avrupa ülkeleri ile rekabet gücünü kıyaslamışlardır. Çalışmada 2013 yılı TTCI raporu ağırlıklı olmak üzere daha önceki raporlardaki veriler birlikte incelenmiştir. Araştırmada bir kısım Avrupa ülkeleri ile Türkiye'nin rekabetçiliğini belirleyen faktörler baz alınmıştır. Rekabet faktörleri raporda düzenleyici çerçeve, iş çevresi ve altyapı ile doğal, kültürel ve beşeri kaynaklar olmak üzere üç kategoride ele alınmıştır. Araştırma sonucunda Türkiye'nin kültürel miras bakımından dünyada ön sıralarda yer aldığı ve hava ulaşımında yapılan yatırımlar ile iyileştirmelerin rekabet gücüne olumlu katkı sağladığı tespit edilmiştir. Buna karşın güvenlik, çevresel sürdürülebilirlik, karayolu ulaşımı ve sağllk-hijyen faktörleri bakımından sıralamada kötü durumda bulunduğu belirlenmiştir. Ilinčić ve Pavlović (2017), Sırbistan'ın turizm rekabetçiliğine ilişkin geçmiş dönem TTCI raporlarını baz alarak ülkenin rekabetçi gücünü öncelikli olarak doğal, kültürel ve insani alt göstergeler açısından rakip yedi ülke ile kıyaslamışlardır.

TTCI raporlarındaki verilerin kullanımına ilişkin yukarıdaki gibi değerlendirilmelere yönelik çalışmaların yanında çeşitli tekniklerin kullanıldığı amprik araştırmalar da mevcuttur. Bu araştırmalarda çok boyutlu ölçekleme (Hassan ve Uşakll, 2013) ve kümeleme analizi (Kayar ve Kozak, 2010), regresyon (Das ve Dirienzo, 2012; Çağllyan ve Göral, 2017) ve korelasyon analizi (Webster ve Ivanov, 2014; Akkuş, 2018), açımlayıcı ve doğrulayıcı faktör analizleri (Dias, 2017) kullanılarak araştırma örneklemindeki ülke veya ülkelerin mevcut rekabet güçlerini oluşturan faktörler arasındaki ilişkileri ve tutarlılıkları analiz edilmiştir. Buna ilave olarak TTCI verilerinin ele alındığ1 çeşitli araştırmalarda çok kriterli karar verme tekniklerinin de kullanıldığ görülmektedir. Bu araştırmalarda araştırmacılar AHP (Crouch, 2011), DEMATEL-tabanlı ANP (DANP) (Peng ve Tzeng, 2012), TOPSIS (Cracolici ve Nijkamp, 2008; Huang ve Peng, 2012; Manap Davras, 2020), ENTROPİ (Cracolici ve Nijkamp, 2008; Göral, 2016), VIKOR (Peng ve Tzeng, 2012; Manap Davras, 2020) ve EDAS (Güllü ve Yılmaz, 2020) gibi çeşitli teknikleri kullanarak ülkelerin rekabetçilik faktörlerine ilişkin ağırlıklandırmalar belirleyerek hiyerarşik sıralamalar oluşturmuşlardır.

Dünya Ekonomik Forumu (WEF) tarafından destinasyonların rekabetçiliğini ortaya koymada her geçen yıl gelişerek önemini arttıran Seyahat ve Turizm Rekabetçilik Endeksine (TTCI) yönelik araştırmalar artmaktadır. Araştırmacıların bu konuda çeşitli yaklaşımlar geliştirerek ülkelerin rekabetçilik düzeylerini ortaya çıkardıkları görülmektedir. Bu çalışma kapsamında WEF'in TTCI 2019 yılı verileri esas alınarak Türkiye'nin mevcut rekabetçilik düzeyinin belirlenebilmesi ve alanyazına katkı sağlanması amaçlanmıştır.

\section{Dünya Seyahat ve Turizm Rekabetçilik Endeksi (TTCI)}

İlk defa 2007 yılında Dünya Ekonomik Forumu'nca yayınlanmaya başlanan Dünya Seyahat ve Turizm Rekabetçilik Endeksi raporu sonu tek rakamla biten yıllarda her iki yılda bir olarak hazırlanmakta ve ülkelerin turizmine yönelik mevcut durumlarını analiz etmede önemli bilgiler sunmaktadır. Rapor, turizm paydaşlarına turist perspektifinden kamu ve özel sektör düzeyinde destinasyonların zayıf ve güçlü yönlerini belirlemede kolaylık sağlamanın yanında turizmin geliştirilmesine ilişkin fırsatları sunmada ve destinasyona yapılacak seyahatlerde ortaya çıkması olası tehditlere karşı politikalar oluşturmada önemli veriler ortaya koymaktadır (Forsyth ve Dwyer, 2009).

Seyahat ve Turizm Rekabetçilik Endeksi 2019 raporu, anket yapılan ülkelerde Seyahat ve Turizm faaliyetlerini kolaylaştırarak yönlendiren dört ana faktör kategorisinde ölçülmektedir. Rapora 
göre, ankete katılan 140 ülkenin analizinde tabii tutulduğu dört ana faktör, on dört alt faktör ve ölçümlemedeki ağırlıkları Şekil 1'de sunulmuştur.

Seyahat ve Turizm Rekabetçilik Endeksi 2019Yılı Faktörleri

\section{Seyahat ve Turizm Rekabetçilik Endeksi}
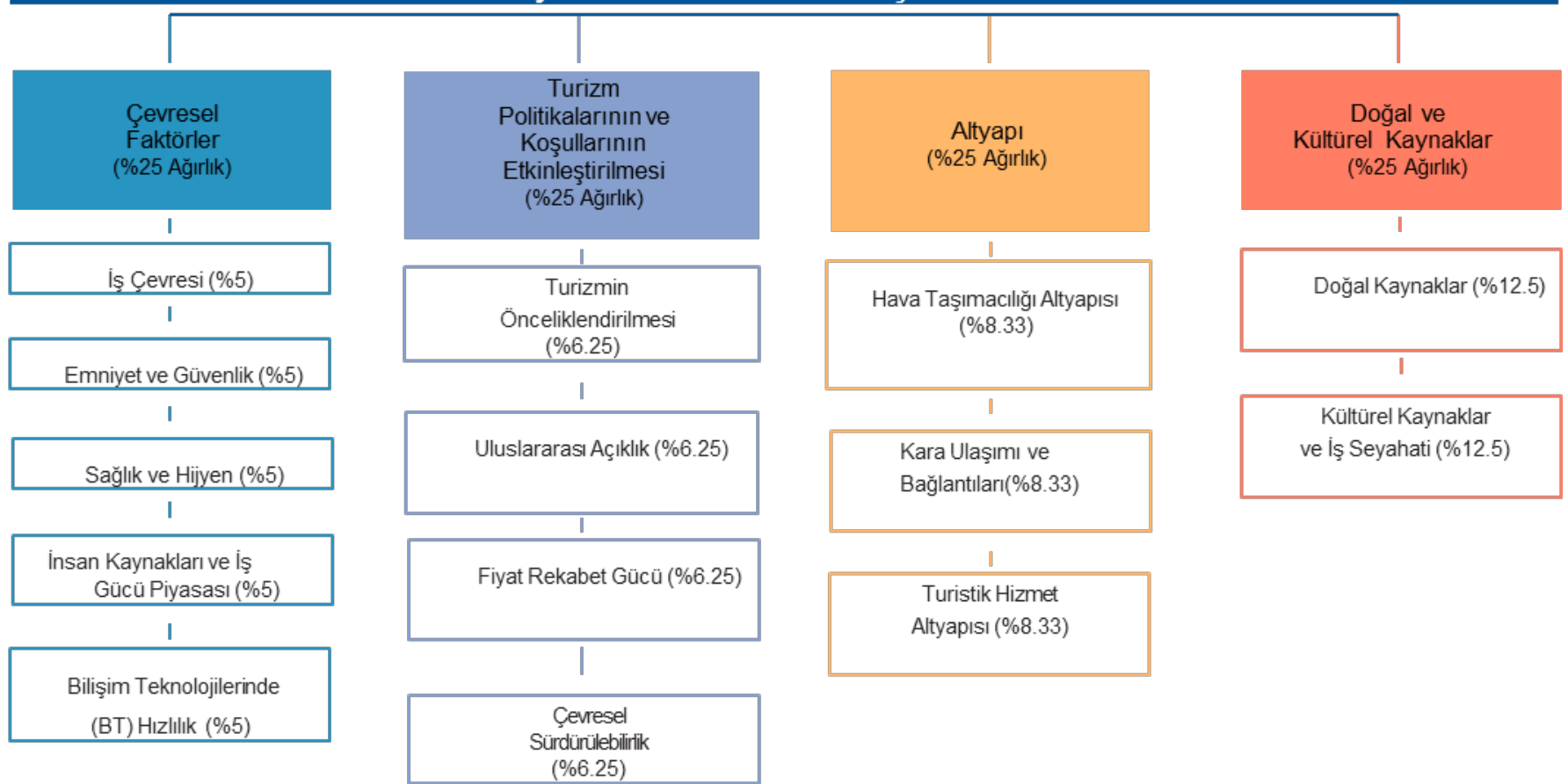

Şekil 1. Seyahat ve Turizm Rekabetçilik Endeksi (TTCI) 2019 Yılı Faktörleri ve Alt Faktörleri

Şekil 1'de TTCI 2019'u oluşturan dört ana faktör ve 14 alt faktör bulunmaktadır. İlgili faktörler ve faktörleri oluşturan alt faktörlerin ölçümünde yararlanılan göstergelere ilişkin bilgiler şöyledir: Alt faktörleri oluşturan toplam 90 gösterge bulunmaktadır. Endeksteki ilk faktör olan ve 5 alt faktörden oluşan "Çevresel Faktörler"in ölçümüne ilişkin; İş Çevresi alt faktöründe 12, Emniyet ve Güvenlik alt faktöründe 5, Sağllk ve Hijyen alt faktöründe 6, İnsan Kaynakları ve İşgücü Piyasası alt faktöründe 9 ve Bilişim Teknolojilerinde Hızlılık alt faktöründe 8 gösterge sayısıyla birlikte toplamda 40 farklı gösterge kullanılmıştır. "Turizm Politikalarının ve Koşullarının Etkinleştirilmesi" faktörünün ölçümüne ilişkin; Turizmin Önceliklendirilmesi alt faktöründe 6, Uluslararası Açıklık alt faktöründe 3, Fiyat Rekabet Gücü alt faktöründe 4 ve Çevresel Sürdürülebilirlik alt faktöründe 10 gösterge sayısıyla birlikte toplam 23 farklı gösterge kullanılmıştır. "Altyapı" faktörünün ölçümüne ilişkin; Hava Taşımacılığı Altyapısı alt faktöründe 6, Kara Ulaşımı ve Bağlantıları alt faktöründe 7 ve Turistik Hizmet Altyapısı alt faktöründe 4 gösterge sayısıla birlikte toplam 17 farklı gösterge kullanılmıştır. "Doğal ve Kültürel Kaynaklar" faktörünün ölçümüne ilişkin olarak da Doğal Kaynaklar ile Kültürel Kaynaklar ve İş Seyahati alt faktörlerinin her birinde 5 'er adet olmak üzere toplam 10 farklı gösterge kullanılmıştır. Ayrıca ağırlıklandırma konusunda dört ana faktöre \%25 şeklinde olmak üzere eşit ağırlık verilmiş olup, her faktörün sahip olduğu alt faktör sayısına oranla da ağrılıkların alt faktörleri arasında eşit dağılım gösterdiği görülmektedir. 
Raporun hesaplamasında yararlanılan göstergelere yönelik veriler birincil ve ikincil kaynaklardan temin edilmiştir. Rapor, Bloom Consulting (BC), STR Global, Uluslararası Hava Taşımacılığı Birliği (IATA), Uluslararası Doğa Koruma Birliği (IUCN), Birleşmiş Milletler İstatistik Departmanı (UNSD), UNESCO, Dünya Seyahat ve Turizm Konseyi (WTTC) ve Dünya Turizm Örgütü (UNWTO) gibi kuruluşlar ile işbirliği içerisinde elde edilen verilerle oluşturulmaktadır. Diğer veri kaynakları ise turizm rekabet endeksi ölçüm hesaplamaları gerçekleştirilen destinasyonlarda yaşayan ve Dünya Ekonomik Forumu'yla birlikte işbirliğinde olan yönetici görüşlerine ilişkin anketlere dayanmaktadır (WEF, 2019).

Birçok uluslararası kaynaktan elde edilen ham veriler başta çeşitli ölçütlere göre düzenlendiklerinden endeks hesaplamasında birlikte kullanılmaya uygun değildirler. Bu sebeple normalize edilebilmesi için veriler 1-7 ölçeğinde " $1=$ son derece zayıf ve $7=$ =son derece güçlü" şeklinde uyumlu hale getirilmişlerdir. Normalizasyon işleminde kullanılan formüller aşağıdadır (WEF, 2019).

$$
-6 x \frac{\text { Ülke Skoru-En Küçük Skor }}{\text { En Büyük Skor-En Küçük Skor }}+7
$$

$$
6 x \frac{\text { Ülke Skoru-En Küçük Skor }}{\text { En Büyük Skor-En Küçük Skor }}+1
$$

Birinci formül, alınan vergiler veya petrol fiyatları gibi yüksek olduğunda ülkelerin rekabetinde olumsuz etkiye sahip değerlere ilişkin normalizasyonda kullanılmıştır. İkinci formül kullanılarak diğer verilere ilişkin değerlerin normalizasyonu yapılmıştır. Alt faktörlere ilişkin en küçük ve en büyük değer "En Büyük ve En Küçük Skor" olarak ifade edilmektedir. Ülkenin ilgili alt faktöre ait değeri ise "Ülke Skoru" şeklinde belirtilmektedir. TTCI puanı hesaplanmasında ilk olarak dört ana faktöre ait kendi alt faktörlerine ilişkin değerlerin 1-7 ölçeğinde ağırlıklandırılmamış aritmetik ortalaması hesaplanarak ana faktör değerlerine ulaşılmıştır. Daha sonrasında elde edilen dört ana faktör değerlerine ilişkin aritmetik ortalama elde edilerek ülkenin endeks puanı hesaplanmıştır. Alt faktör değerlerine ilişkin göstergeler, seyahat ve turizm ile daha çok doğrudan bağlantılı hale geldikçe alt faktör sayısı azalırken ağırlıkları artmaktadır. Örneğin Turistik Hizmet Altyapısı $(\% 8,33)$ alt faktörü, İş Çevresi (\%5) alt faktöründen daha ağırdır. Bunun sebebi turizm altyapısının en çok turizm endüstrisiyle ilgili olmasından kaynaklanmaktadır. İş Çevresi alt faktöründe toplanan veriler ise, ülkedeki iş ve hizmetleri etkileyen daha geniş bir faktör kümesini temsil etmektedir (WEF, 2019).

\section{Çevresel Faktörler}

İ̧̧ Çevresi: On iki göstergeden oluşan bu alt faktör, bir ülkenin şirketlere iş yapmaları için elverişli bir politika ortamına ne ölçüde sahip olduğunu göstermektedir. Araştırmalar, ekonomik büyüme ile mülkiyet haklarının ne kadar iyi korunduğu ve yasal çerçevenin etkinliği gibi hususlar arasında önemli bağlantılar olduğunu belirtmektedir. Benzer şekilde bir ülkenin verimliliğini ve üretkenliğini etkileyen, vergilendirme ve rekabet politikasındaki bozulmalar hem yurtiçi hem de uluslararası rekabet dahil, doğrudan yabancı yatırımı kolaylaştırma açısından ölçülmektedir. Bu faktörler Seyahat ve Turizm dahil tüm sektörler için önemlidir. Buna ek olarak, özellikle Seyahat ve Turizmi geliştirme için önemli bir konu olan inşaat izinleriyle başa çıkmak için gereken maliyet ve zaman unsurları da dikkate alınmaktadır (WEF, 2019).

Emniyet ve Güvenlik: Beş göstergeden oluşan Emniyet ve Güvenlik alt faktörü bir ülkenin Seyahat ve Turizm endüstrisinin rekabet gücünü belirleyen kritik faktörlerinden biridir. Turistlerin 
tehlikeli ülke veya bölgelere seyahat etmekten caydırılması muhtemeldir, bu da ilgili yerlerde Seyahat ve Turizm endüstrisini geliştirmeyi daha az çekici hale getirmektedir. Burada terörizmin yanı sıra ortak suç ve şiddetin maliyeti ve suçtan koruma sağlamak için polis hizmetlerine ne ölçüde güvenilebileceği dikkate alınmaktadır. Bu alt faktörde Dünya Ekonomik Formu raporunda elde edilen veriler; polis hizmetlerinin güvenilirliği, şiddet ve suçun ticari maliyetleri, terörün işletme maliyetleri, cinayet oranı ve terör olayları indeksi gibi derecelendirmelerden oluşturulmaktadır (WEF, 2019).

Sağllk ve Hijyen: Sağlık ve Hijyen alt faktöründe altı gösterge bulunmaktadır. Seyahat ve Turizm rekabet gücü için gerekli olan bu alt faktörde, yolcuların rahatı ve sağlığı için iyileştirilmiş içme suyu ve sanitasyona erişim önemlidir. Turistlerin hastalanması durumunda, ülkenin sağlık sektörü, doktorların ve hastane yataklarının mevcudiyeti ile ölçüldüğü üzere, turistlere uygun şekilde bakılmalarını sağlayabilmelidir. Ek olarak, yüksek HIV ve sıtma prevalansı, Seyahat ve Turizm iş gücünün üretkenliği üzerinde bir etkiye sahip olabilmektedir ve turistlerin bir ülkeyi ziyaret etmelerinin caydırılmasında rol oynayabilmektedir (WEF, 2019). Covid-19 salginıyla birlikte bu faktörün sıralamalarda daha da önemli hale geldiği söylenebilir.

İnsan Kaynakları ve İş Gücü Piyasası: Bir ekonomideki yüksek kaliteli insan kaynakları, ülke endüstrinin ihtiyaç duyduğu işbirlikçilere erişimini sağlamaktadır. Dokuz göstergeye sahip olan bu alt faktörün bileşenleri, ülkelerin eğitim ve öğretim yoluyla becerileri ne kadar iyi geliştirdiğini ölçmekte ve bu becerilerin verimli bir iş gücü piyasası aracılığıyla en iyi dağılımını geliştirmektedir. Insan Kaynakları, örgün eğitim kazanım oranlarını ve eğitim hizmetlerine ve müşteri hizmetlerine iş yatırımı gibi insan kaynaklarının iyileştirilmesine özel sektör katılımını içermektedir. İşgücü Piyasası, ülkenin yetenek havuzunun derinliğini ve insan kaynaklarını en iyi şekilde kullanmak üzere tahsis etme kabiliyetini değerlendirmek için iş gücü piyasasının esnekliğii, etkinliği ve açıklığı ile kadınların katılımına ilişkin önlemleri içermektedir (WEF, 2019).

Bilişim Teknolojilerinde Hızlılık: İnternetin gezi planlaması ile seyahat ve konaklama rezervasyonu için kullanılmasıyla Seyahat ve Turizmde çevrimiçi hizmetler ve iş operasyonlarının önemi giderek artmaktadır. Bununla birlikte, bilişim teknolojileri artık tüm sektörler için o kadar yaygındır ve önemlidir ki, genel olanak sağlayan ortamın bir parçası olarak kabul edilmektedir. Sekiz göstergeye sahip bu alt faktörün bileşenleri, yalnızca modern sabit altyapının varlığını (mobil ağ kapsamı ve elektrik tedarikinin kalitesini) değil, aynı zamanda işletmelerin ve bireylerin çevrimiçi hizmetleri kullanma ve sağlama kapasitesini de ölçmektedir (WEF, 2019).

\section{Turizm Politikaları ve Koşulların Etkinleştirilmesi}

Turizmin Önceliklendirilmesi: Devletin seyahat ve turizm endüstrisine ne ölçüde öncelik verdiği seyahat ve turizm rekabet gücü üzerinde önemli bir etkiye sahiptir. Devlet, endüstrinin birincil endişe kaynağı olduğunu açıkça ortaya koyarak, fonları temel kalkınma projelerine kanalize edebilmekte ve turizm endüstrisinin geliştirilmesi için ihtiyaç duyulan kaynakları koordine edebilmektedir. Devlet politikasının istikrarını işaret etmek, sektörün daha fazla özel yatırım çekme kabiliyetini etkileyebilir. Devlet ayrıca, ulusal ve uluslararası pazarlama kampanyaları yoluyla turistleri doğrudan çekmede önemli bir rol oynayabilir. Altı göstergeye sahip olan bu alt faktör, bir ülkenin Seyahat ve Turizm sektörüne verdiği önemi gösterdiği için, devlet harcamaları, pazarlama kampanyalarının ve ülke markalaşmasının etkinliği ile uluslararası kuruluşlara Seyahat ve Turizm verilerinin tamlığı ve zamanlılığ ile ilgili ölçümleri içermektedir (WEF, 2019).

Uluslararası Açıklı: Uluslararası anlamda rekabetçi bir Seyahat ve Turizm endüstrisi geliştirmek, belirli bir derecede açıklık ve seyahat kolaylığı gerektirir. Hantal vize gereksinimleri gibi 
kısıtlayıcı politikalar, turistlerin bir ülkeyi ziyaret etme istekliliğini azaltır ve dolaylı olarak temel hizmetlerin kullanılabilirliğini azaltmaktadır. Üç göstergeye sahip olan bu alt faktörde ölçülen bileşenler, dünya standartlarında turizm hizmetleri sunmak için devletin anlaşma sağladığı ve ülkenin hava bağlantılarının mevcudiyetini etkileyen ikili hava hizmeti anlaşmalarının açıklığını ve bu anlaşmaları mümkün olduğu ölçüde temsil eden yürürlükteki bölgesel ticaret anlaşmalarının sayısını içermektedir (WEF, 2019).

Fiyat Rekabet Gücü: Bir ülkede seyahatle ilgili daha düşük maliyetler, Seyahat ve Turizm sektörüne yatııım yapılmasının yanı sıra birçok gezgin için ülkenin çekiciliğini de arttırmaktadır. Dört göstergeye sahip bu alt faktörde dikkate alınan bileşenler, fiyat rekabetçiliği unsurları arasında uçak bileti vergileri ve uçak biletlerini çok daha pahalı hale getirebilecek havalimanı ücretleri; otel konaklamalarının maliyetleri satın alma gücü paritesiyle temsil edilen yaşam maliyeti ve seyahat maliyetini doğrudan etkileyen yakıt fiyatı maliyetlerinden oluşmaktadır (WEF, 2019).

Çevresel Sürdürülebilirlik: Turizm için çekici bir konum sağlamada doğal çevrenin önemi abartılamaz, bu nedenle çevresel sürdürülebilirliği arttıran politikalar ve faktörler, bir ülkenin varış noktası olarak gelecekteki çekiciliğini sağlamada önemli bir rekabet avantajıdır. On göstergeye sahip bu alt faktörün bileşenleri, devletin çevre düzenlemelerinin katılığı ve uygulanması gibi politika göstergeleri ile su, orman kaynakları ve deniz yaşamının durumunu değerlendiren ve balık stoku durumuna bağlı olan değişkenlerden oluşmaktadır. Turizmin kendisinin çevresel etkileri göz önüne alındığında, Seyahat ve Turizm sektörünün sürdürülebilir bir şekilde ne ölçüde geliştirildiği de hesaba dahil edilmektedir (WEF, 2019).

\section{Altyap1}

Hava Taşımacılı̆̆ı Altyapısı: Hava bağlantısı, yolcuların ülkelere ve ülkelerden erişim kolaylığı ve ayrıca birçok ülke içindeki hareketleri için çok önemlidir. Dört göstergeye sahip bu alt faktörde, uçakların mevcut koltuk sayısı, kilometresi, kalkış sayısı, havalimanı yoğunluğu ve havayollarında çalışan sayısı ile iç ve dış hatlar için hava taşımacılığı altyapısının kalitesi gibi göstergeleri kullanarak hava taşımacılığı miktarı ölçülmektedir (WEF, 2019).

Kara Ulaşımı ve Bağlantıları: Önemli iş merkezlerine ve turistik yerlere verimli ve erişilebilir ulaşımın mevcudiyeti Seyahat ve Turizm endüstrisi için hayati önem taşımaktadır. Bu, uluslararası konfor, güvenlik ve verimlilik standartlarını karşılayan karayolu ve demiryolu yoğunluklarının yanı sıra karayolları, demiryolları ve liman altyapısı ile temsil edilen yeterince kapsamlı bir karayolu ve demiryolu ağı gerektirmektedir. Yedi göstergeye sahip bu alt faktörde bileşenler, yerel bağlantıları mümkün kılan ve belirli bir dereceye kadar çok özel bağlamlarda turistleri çekebilen göz alıcı yolların varlığını temsil eden asfaltsız yolları da hesaba dahil edilerek ölçülmektedir (WEF, 2019).

Turistik Hizmet Altyapısı: Yeterli kalitede konaklama, tatil köyleri ve eğlence tesislerinin mevcudiyeti, bir ülke için önemli bir rekabet avantajı sağlayabilmektedir. Dört göstergeye sahip bu alt faktörün bileşenlerinde, Araç kiralama ve ATM gibi hizmetlere erişim kapsamının yanında tamamlanmakta olan otel oda sayıları ile turizm hizmet altyapısının seviyesi ölçülmektedir (WEF, 2019).

\section{Doğal ve Kültürel Kaynaklar}

Doğal Kaynaklar: Doğal varlıkları olan ülkeler turist çekmede açık bir biçimde rekabet avantajına sahiptirler. Beş göstergeye sahip bu alt faktörün bileşenleri içerisinde, UNESCO Doğal Dünya Mirası alanlarının sayısı, peyzajının güzelliğini temsil eden doğal çevrenin kalitesinin ölçüsü, ülkedeki faunanın zenginliği, toplam bilinen hayvan türleri, milli parkların ve doğa koruma 
alanlarının kapsamını temsil etmekte olan ulusal olarak korunan alanların yüzdesi gibi bir dizi çekicilik ölçüsü bulunmaktadır (WEF, 2019).

Kültürel Kaynaklar ve İş Seyahati: Bir ülkenin kültürel kaynakları, Seyahat ve Turizm rekabet gücünün bir başka kritik etkenidir. Beş göstergeye sahip bu alt faktörün bileşenlerinde yer alan kaynaklar, ilgi düzeyinin anlaşılmasına izin verebildiğinden, UNESCO Kültürel Dünya Mirası alanlarının sayısı, önemli spor veya eğlence etkinliklerine ev sahipliği yapabilecek büyük stadyumların sayısı, kültür ve eğlence için dijital talep ölçümleri, bir ülkenin kültürel mirasıyla ilgili çevrimiçi arama sayısı ölçümlere dahil edilmektedir. Bir ülkede gerçekleşen uluslararası toplantıların sayısı, en azından kısmen iş seyahatlerini yakalamak için de hesaplamalara katılmaktadır (WEF, 2019).

\section{Seyahat ve Turizm Rekabetçilik Endeksi 2019 Yılı Türkiye Görünümü}

Dünya Ekonomik Forumu (WEF) internet sitesindeki TTCI 2019 Türkiye verilerine ilişkin genel bilgiler Şekil 2'de sunulmaktadır.

\section{Türkiye}

43. $/ 140$

Seyahat ve Turizm Rekabetçilik Endeksi 2019 Yılı Yayını

\begin{tabular}{|c|c|c|c|}
\hline \multirow{2}{*}{$\begin{array}{l}\text { Temel Göstergeler } \\
\text { Uluslararası turist var }\end{array}$} & \multirow[b]{2}{*}{$37,603,000$} & \multicolumn{2}{|c|}{ Kaynaklar: Dünya Turizm Örgütü (UNWTO) ve Dünya Seyahat ve Turizm Konseyi (WTTC } \\
\hline & & Turizm endüstrisi GSYiH oranı \% GSYïH & 4.3 \\
\hline Uluslararası turizm gelen gelirleri & US $\$ 22,478.0$ milyon & Turizm endüstrisi istihdamı & 532,100 işgören \\
\hline Varış başına ortalama gelir & US $\$ 597.8$ & $\%$ toplam & $\% 1.8$ \\
\hline $\begin{array}{l}\text { Turizm endüstrisi GSYIH } \\
\% \text { toplam }\end{array}$ & $\begin{array}{r}\text { US } \$ 33,783.9 \text { milyon } \\
\% 4.3\end{array}$ & 1 & işgören 1.8 \\
\hline
\end{tabular}

\section{Genel Performans}

Gösterge

Puan

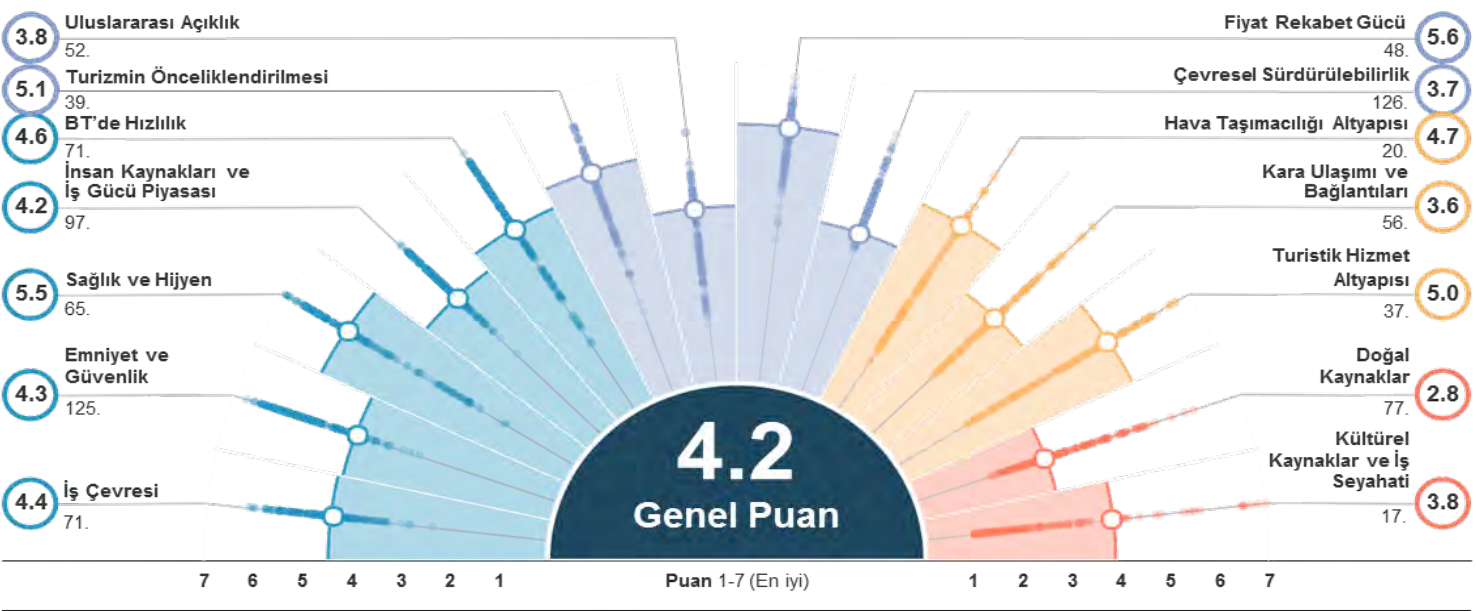

Geçmiş performanslar

\begin{tabular}{llll}
\hline Seyahat ve Turizm Rekabetçilik Yayını & $\mathbf{2 0 1 5}$ & $\mathbf{2 0 1 7}$ & $\mathbf{2 0 1 9}$ \\
\hline Sıralama & $44 / 141$ & $44 / 136$ & $43 / 140$ \\
\hline Puan & 4.1 & 4.1 & 4.2
\end{tabular}

Şekil 2. Seyahat ve Turizm Rekabetçilik Endeksi 2019 Yılı Türkiye Görünümü 
Seyahat ve Turizm Rekabetçilik Endeksi (TTCI) ülke sayfası raporu; Temel Göstergeler, Genel Performans ve Geçmiş Performanslar olmak üzere üç bölümden oluşmaktadır.

Dünya Turizm Örgütü (UNWTO) ve Dünya Seyahat ve Turizm Konseyi (WTTC)'nin verileriyle elde edilen Temel Göstergeler bölümünde; Türkiye'nin Uluslararası Turist Varışlarında 37.603.000 adet varışa ulaştı̆̆ı, Uluslararası Turizm Gelen Gelirlerinde 22.478 milyon \$ gelir sağladığı, Varış Başına Ortalama Gelirin 597,8 \$ olduğu, Turizm Endüstrisi doğrudan GSYìH'nin 33.783,9 milyon \$ ile toplam GSYİH içerisindeki payının \% 4,3'ünü ve Turizm Endüstrisi istihdamının 532.100 çalışan ile toplam istihdamın \% 1,8'ini oluşturduğu belirtilmektedir.

Genel Performans bölümünde; Türkiye'nin genel puanı 4.2'dir. Ayrıca bu bölümde TTCI raporunu oluşturan dört ana faktörün on dört alt faktörüne ilişkin puanları ve her bir alt faktöre göre Türkiye'nin sıralaması yer almaktadır. İlgili puanlamalar 1-7 ölçeğinde (1= son derece zayıf, $7=$ son derece güçlü) normalize edilmiş puanlardan oluşmaktadır. Türkiye'nin her bir ana faktörü ve alt faktörlerine yönelik sıralamaları bulgular bölümünde ayrı tablolar halinde belirtilerek alt faktörleri oluşturan göstergelerdeki sıralamalar ile birlikte sunulmuştur.

Geçmiş Performanslar bölümünde; 2019 yılı ile birlikte 2015 ve 2017 yıllarının genel sıralama ve genel puanları belirtilmektedir. Buna göre Türkiye, TTCI'nin son iki geçmiş raporunda da 2015 ve 2017 yıllarında 4.1 genel puan ile 44'üncü genel sıralamada yer almıştır. 2017 yılındaki raporda ülke sayısının 2015 yılına göre beş ülke azalarak 136 olmasına rağmen Türkiye'nin sıralamasının değişmediği görülmektedir. Normalize edilen puan ağırlıklarının rapordaki ülke sayısına bağlı olarak değiştiği ele alındığında 2015 ve 2017 yıllarındaki aynı sıralamada görünüm sergilemesine rağmen Türkiye'nin 44'üncü sıralamasında sabit kalması, 2017 yılında genel olarak 2015 yılına göre olumsuz bir performans sergilediğini göstermektedir. 2019 yılında Türkiye'nin genel puanlamada 0.1 puan artış yakalayarak 4.2 genel puan ile genel sıralamada bir basamak yükseldiği ve 43'üncü sırada yer aldığı görülmektedir. Buna karşın 2019 yılında 2017 yılına göre dört ülke TTCI raporuna dahil edilerek 140 ülke üzerinden puanlamalar normalize edilmiştir. TTCI raporlarından çıkarılan ve raporlara dahil edilen ülke sayılarına bağlı olarak Türkiye'nin 2015 yılına göre 2017 yılındaki sıralamasından daha geride ve 2017 yılına göre 2019 yılında bulunan sıralamasından da daha ileride bir performans gösterdiği söylenebilir. Bu durum Türkiye turizminin özellikle son dönemde 2014, 2015 ve 2016 yıllarında yaşanan krizlerden hızla toparlanarak çıktığını da desteklemektedir.

\section{YÖNTEM}

Bu çalışma, Dünya Ekonomik Forumu'nca yürütülen 140 ülkenin Seyahat ve Turizm Rekabetçilik Endeksi (TTCI) 2019 raporuna dayanmaktadır. Nitel araştırma yaklaşımının esas alındığı bu çalışmada veri toplama tekniği olarak doküman inceleme ve verilerin çözümlenmesinde betimsel analiz teknikleri kullanılmıştır. Çalışmada Dünya Ekonomik Forumu'nun sunduğu veriler kullanıldığından ortaya çıkarılan bulguların güvenirlik ve geçerliği TTCI raporunda sunulan verilerin güvenirliğine ve geçerliğine bağlıdır. Araştırmada, TTCI 2019 raporundaki her bir ana faktör grubuna bağlı olan alt faktör ve göstergelere ilişkin değerlerin 140 ülke arasındaki sıralamaları içerisinde Türkiye'nin rekabetçi gücü ortaya konmaya çalışılmıştır. Değerlendirmelerde Bello ve arkadaşlarının 2014 yılında Nijerya için ve Göral'ın 2017 yılında Türkiye için yapmış olduğu benzer araştırma yaklaşımı benimsenerek ülke sıralamaları 5'li gruplara ayrılmıştır. Bu çalışmanın önemi, son rapor kapsamında Türkiye'nin rekabetçi faktörler tarafından analiz edilmesi ve 2015-2017-2019 yıllarına ilişkin raporlar kapsamında rekabetçilik faktörleri açısından Türkiye'nin rekabetçi durumunda farklılık olup olmadığının değerlendirilmesidir. Türkiye'nin rapordaki konumu beş puanlık likert ölçeğine dayanan 
sıralama üzerinden her bir ana faktör grubunda ayrı bir biçimde sunularak mevcut durum analizi yapılmışır. Tablo 1'de gruplar ve tanımları sunulmaktadır.

Tablo 1. Gruplar ve Tanımları

\begin{tabular}{|l|l|l|}
\hline Gruplar & Sıralama & Grup Tanımı \\
\hline $\mathbf{1 .}$ & $1-30$ & Çok iyi \\
\hline $\mathbf{2 .}$ & $31-60$ & İyi \\
\hline $\mathbf{3 .}$ & $61-90$ & Orta \\
\hline $\mathbf{4 .}$ & $91-120$ & Zayıf \\
\hline $\mathbf{5 .}$ & $121-140$ & Çok zayıf \\
\hline
\end{tabular}

Tablo 1'de bir ülke, sıralamada 5. gruba (121-140) giriyorsa Çok Zayıf; 4. gruba (91-120) giriyorsa Zayıf; 3. gruba (61-90) giriyorsa Orta; 2. gruba (31-60) giriyorsa İyi; 1. gruba (1-30) giriyorsa Çok iyi biçiminde değerlendirilmektedir. Bu ölçeklendirme modeli, analizi yapılan ülkenin turizmini geliştirmek için çekici kılan faktörlerin ve politikaların mevcut durumunun daha kolay yorumlanmasına yardımcı olabilecektir (Bello vd., 2014:9; Göral, 2017:155). Ayrıca araştırmada 2015, 2017 ve 2019 yıllarında yayınlanan TTCI raporu doğrultusunda Türkiye'nin Seyahat ve Turizm Rekabetçilik endeksi faktörleri kapsamındaki karşılaştırılması yapılmıştır.

\section{BULGULAR}

2019 yılı TTCI raporunda genel sıralamada 43'üncü olan Türkiye, beşli grup ölçeğine göre 2. grup olan (31-60) "İyi” durumda bir görünüm sergilemiştir. Araştırmanın bu bölümünde TTCI 2019 raporunda bulunan faktörler ve bu faktörleri oluşturan alt faktörler ile göstergeler Türkiye bağlamında sırasıyla ele alınmıştır.

\section{Seyahat ve Turizm Rekabetçilik Endeksi (TTCI) Çevresel Faktörler Değerlendirmesi}

TTCI 2019 yılı raporuna göre "Çevresel Faktörler"i oluşturan alt faktörler; İ̧̧ Çevresi, Emniyet ve Güvenlik, Sağlık ve Hijyen, İnsan Kaynakları ve İş Gücü Piyasası ile Bilişim Teknolojilerinde Hızlılık şeklindedir. Çevresel Faktörler bir ülkedeki işletmecilik çevresine ilişkin gerekli genel düzenlemeleri değerlendirmektedir (WEF, 2019). Tablo 2' de 2019 yılı TTCI raporundaki Çevresel Faktörleri oluşturan alt faktörlerin beşli grup ölçeğine göre Türkiye'nin sıralamaları ve yer aldığı gruplar sunulmaktadır. Bu faktörde Türkiye'nin genel faktör sıralaması 82'nci sırada olup "Orta" düzeyde bir görünüm sergilediği görülmektedir.

İş Çevresi: Türkiye, TTCI 2019 raporunda 140 ülke arasında "İş Çevresi” alt faktöründe 4.4 puanla 71'inci sırada "Orta" düzeyde bir görünüm sergilemiştir. Raporda İ̧̧ Çevresi alt faktörü kapsamında değerlendirmeye alınan 12 gösterge ile Türkiye'nin bu göstergelerdeki sıralamaları ve performansları; Mülkiyet hakları (96-zayıf), Kuralların DYY (Doğrudan Yabancı Yatırımlar) üzerindeki ticari etkisi (64-orta), Uyuşmazlıkların çözümünde yasal çerçevenin etkinliği (90-orta), 
Zorlayıcı düzenlemelerde yasal çerçevenin etkinliği (109-zayıf), İnşaat izinleri için gereken süre (37-iyi), İnşaat izinleriyle başa çıkma maliyeti (92-zayıf), Pazar hakimiyetinin kapsamı (86-orta), İş kurma zamanı (43-iyi), Bir iş kurmanın maliyeti (82-orta), Vergilendirmenin işe teşviklere etkisi (80-orta), Vergilendirmenin yatırım teşvikleri üzerindeki etkisi (73-orta) ve Toplam vergi oranı (85-orta) şeklindedir.

Tablo 2. TTCI 2019 Yılı Çevresel Faktörlere İlişkin Türkiye Sıralamaları

\begin{tabular}{|c|c|c|c|c|c|}
\hline Faktörler & $\begin{array}{l}\text { Çok iyi } \\
\text { (1-30. } \\
\text { sira) }\end{array}$ & $\begin{array}{c}\text { İyi } \\
(31-60 . \\
\text { sira) }\end{array}$ & $\begin{array}{c}\text { Orta } \\
(61-90 . \\
\text { sira })\end{array}$ & $\begin{array}{c}\text { Zaylf } \\
\text { (91-120. } \\
\text { sira) }\end{array}$ & $\begin{array}{c}\text { Çok Zayılf } \\
\text { (121-140. } \\
\text { sira) }\end{array}$ \\
\hline İş Çevresi & & & $71(4.4)$ & & \\
\hline Emniyet ve Güvenlik & & & & & $125(4.3)$ \\
\hline Sağlık ve Hijyen & & & $65(5.5)$ & & \\
\hline $\begin{array}{l}\text { İnsan Kaynakları ve İşs } \\
\text { Gücü Piyasası }\end{array}$ & & & & $97(4.2)$ & \\
\hline $\begin{array}{l}\text { Bilişim Teknolojilerinde } \\
\text { Hızlılık }\end{array}$ & & & $71(4.6)$ & & \\
\hline Genel Faktör Sıralaması & & & 82 & & \\
\hline
\end{tabular}

Emniyet ve Güvenlik: Türkiye, Seyahat ve Turizm Rekabetçilik Endeksi 2019 raporunda 140 ülke arasında "Emniyet ve Güvenlik" alt faktöründe 4.3 puanla 125'inci sırada "Çok zayıf" düzeyde bir görünüm sergilemiştir. Raporda Emniyet ve Güvenlik alt faktörü kapsamında değerlendirmeye alınan 5 gösterge ile Türkiye'nin bu göstergelerdeki sıralamaları ve performansları; Suç ve şiddetin ticari maliyetleri (106-zayıf), Polis hizmetlerinin güvenilirliği (90-orta), Terörizmin ticari maliyetleri (128-çok zayıf), Terörizm vakası indeksi (134-çok zayıf) ve Cinayet oranı (83-orta) şeklindedir.

Sağllk ve Hijyen: Türkiye, Seyahat ve Turizm Rekabetçilik Endeksi 2019 raporunda 140 ülke arasında "Sağllk ve Hijyen" alt faktöründe 5.5 puanla 65'inci sırada "Orta" düzeyde bir görünüm sergilemiştir. Raporda Sağllk ve Hijyen alt faktörü kapsamında değerlendirmeye alınan 6 gösterge ile Türkiye'nin bu göstergelerdeki sıralamaları ve performansları; Hekim yoğunluğu (72-orta), Temel sanitasyon hizmetlerinin kullanımı (50-iyi), Temel içme suyu hizmetlerinin kullanımı (49iyi), Hastane yatakları (60-iyi), HIV yaygınlığı (1-çok iyi) ve Sıtma Vakası (1-çok iyi) şeklindedir.

İnsan Kaynakları ve İşgücü Piyasası: Türkiye, Seyahat ve Turizm Rekabetçilik Endeksi 2019 raporunda 140 ülke arasında "İnsan Kaynakları ve İşücü Piyasası" alt faktöründe 4.2 puanla 97'inci sırada "Zayıf" düzeyde bir görünüm sergilemiştir. Raporda İnsan Kaynakları ve İşgücü Piyasası alt faktörü kapsamında değerlendirmeye alınan 9 gösterge ile Türkiye'nin bu göstergelerdeki sıralamaları ve performansları; İlköğretime kayıt oranı (77-orta), Orta öğretime kayıt oranı (35-iyi), Personel eğitiminin kapsamı (107-zayıf), Müşteri odaklılık derecesi (71-orta), İşe alma ve işten çıarma uygulamaları (102-zayıf), Kalifiye eleman bulma kolaylığı (117-zayıf), Yabancı işçi çalıştırma kolaylığı (83-orta), Ödeme ve verimlilik (95-zayıf) ile Kadınların işgücüne katılımı (126-çok zayıf) şeklindedir.

Bilişim Teknolojilerinde Hizlılık: Türkiye, Seyahat ve Turizm Rekabetçilik Endeksi 2019 raporunda 140 ülke arasında "Bilişim Teknolojilerinde Hızlılık" alt faktöründe 4.6 puanla 71'inci sırada "Orta" düzeyde bir görünüm sergilemiştir. Raporda Bilişim Teknolojilerinde Hızlılık" alt faktörü kapsamında değerlendirmeye alınan 8 gösterge ile Türkiye'nin bu göstergelerdeki sıralamaları ve performansları; B2B (Firmadan firmaya) işlemler için bilişim teknolojilerinin kullanımı (72- 
orta), B2C (Firmadan tüketiciye) işlemler için internet kullanımı (59-iyi), internet kullanıcılarının oranı (66-orta), sabit geniş bant internet abonelikleri (59-iyi), mobil-hücresel telefon abonelikleri (103-zayıf), mobil geniş bant abonelikleri (64-orta), Mobil ağ kapsamı (46-iyi) ve Elektrik arzının kalitesi (89-orta) şeklindedir.

\section{Seyahat ve Turizm Rekabetçilik Endeksi (TTCI) Turizm Politikaları ve Koşulların Etkinleştirilmesi Faktörünün Değerlendirmesi}

TTCI 2019 yılı raporuna göre "Turizm Politikaları ve Koşulların Etkinleştirilmesi” faktörünü oluşturan alt faktörler; Turizmin Önceliklendirilmesi, Uluslararası Açıklık, Fiyat Rekabet Gücü ve Çevresel Sürdürülebilirlik şeklindedir. Bu faktör bir ülkedeki seyahat ve turizm endüstrisini daha doğrudan etkileyen belirli politikaları ve stratejik görünümü değerlendirmektedir (WEF, 2019). Tablo 3'de 2019 yılı TTCI raporundaki Turizm Politikaları ve Koşulların Etkinleştirilmesi faktörlerini oluşturan alt faktörlerin beşli grup ölçeğine göre Türkiye'nin sıralamaları ve yer aldığı gruplar sunulmaktadır. Bu faktörde Türkiye'nin genel faktör sıralaması 56'ncı sırada olup "İyi" düzeyde bir görünüm sergilemiştir.

Tablo 3. TTCI 2019 Yılı Turizm Politikaları ve Koşulların Etkinleştirilmesi Faktörüne İlişkin Türkiye Sıralamaları

\begin{tabular}{lccccc}
\hline Faktörler & $\begin{array}{c}\text { Çok iyi } \\
(\mathbf{1 - 3 0 .}\end{array}$ & $\begin{array}{c}\text { İyi } \\
\mathbf{( 3 1 - 6 0 .}\end{array}$ & $\begin{array}{c}\text { Orta } \\
\mathbf{( 6 1 - 9 0 .} \\
\text { sıra) }\end{array}$ & $\begin{array}{c}\text { Zayıf } \\
\mathbf{( 9 1 - 1 2 0 .} \\
\text { sıra) }\end{array}$ & $\begin{array}{c}\text { Çok Zayıf } \\
\mathbf{( 1 2 1 - 1 4 0 .} \\
\text { s1ra) }\end{array}$ \\
\hline $\begin{array}{l}\text { Turizmin } \\
\text { Önceliklendirilmesi }\end{array}$ & $39(5.1)$ & & & \\
Uluslararası Açklık & & $52(3.8)$ & & & \\
Fiyat Rekabet Gücü & & $48(5.6)$ & & & $126(3.7)$ \\
$\begin{array}{l}\text { Çevresel } \\
\text { Sürdürülebilirlik }\end{array}$ & & & & \\
$\begin{array}{l}\text { Genel Faktör } \\
\text { Sıralaması }\end{array}$ & & 56 & & \\
\hline
\end{tabular}

Turizmin Önceliklendirilmesi: Türkiye, Seyahat ve Turizm Rekabetçilik Endeksi 2019 raporunda 140 ülke arasında "Turizmin Önceliklendirilmesi" alt faktöründe 5.1 puanla 39'uncu sırada "İyi" düzeyde bir görünüm sergilemiştir. Raporda Turizmin Önceliklendirilmesi alt faktörü kapsamında değerlendirmeye alınan 6 gösterge ile Türkiye'nin bu göstergelerdeki sıralamaları ve performanslarl; Devletin seyahat ve turizm endüstrisine öncelik vermesi (61-orta), Seyahat ve Turizme yönelik devlet bütçesi (30-çok iyi), Turist çekmek için pazarlama ve markalaşmanın etkinliği (87-orta), Seyahat ve Turizm yıllık verilerinin kapsamlılı̆̆ (7-çok iyi), Seyahat ve Turizm verilerini aylık/üç aylık sağlamanın zamanında yapılması (8-çok iyi) ve Ülke marka stratejisi değerlendirmesi (109-zayıf) şeklindedir.

Uluslararası Açıklık: Türkiye, Seyahat ve Turizm Rekabetçilik Endeksi 2019 raporunda 140 ülke arasında "Uluslararası Açıklık" alt faktöründe 3.8 puanla 52'nci sırada "İyi" düzeyde bir görünüm sergilemiştir. Raporda Uluslararası Açıklk alt faktörü kapsamında değerlendirmeye alınan 3 gösterge ile Türkiye'nin bu göstergelerdeki sıralamaları ve performansları; Vize gereksinimleri (53-iyi), İkili hava hizmet anlaşmalarının açılı̆̆ğ (61-orta) ve Yürürlükteki bölgesel ticaret anlaşmalarının sayısı (42-iyi) şeklindedir. 
Fiyat Rekabet Gücü: Türkiye, Seyahat ve Turizm Rekabetçilik Endeksi 2019 raporunda 140 ülke arasında "Fiyat Rekabet Gücü" alt faktöründe 5.6 puanla 48'inci sırada "İyi" düzeyde bir görünüm sergilemiştir. Raporda Fiyat Rekabet Gücü alt faktörü kapsamında değerlendirmeye alınan 4 gösterge ile Türkiye'nin bu göstergelerdeki sıralamaları ve performansları; Bilet vergileri ve havalimanı ücretleri (29-çok iyi), Otel fiyat endeksi (8-çok iyi), Satın alma gücü paritesi (42-iyi) ve Yakıt fiyatı seviyeleri (122-çok zayıf) şeklindedir.

Çevresel Sürdürülebilirlik: Türkiye, Seyahat ve Turizm Rekabetçilik Endeksi 2019 raporunda 140 ülke arasında "Çevresel Sürdürülebilirlik" alt faktöründe 3.7 puanla 126'ncı sırada "Çok zayıf" düzeyde bir görünüm sergilemiştir. Raporda Çevresel Sürdürülebilirlik alt faktörü kapsamında değerlendirmeye alınan 10 gösterge ile Türkiye'nin bu göstergelerdeki sıralamaları ve performansları; Çevre düzenlemelerinin sıkılı̆̆ı (94-zayıf), Çevre düzenlemelerinin uygulanması (90-orta), Seyahat ve Turizm endüstrisinin gelişiminin sürdürülebilirliği (61-orta), Partikül madde konsantrasyonu (87-orta), Çevre anlaşması onayı (125-çok zayıf), Temel su stresi (114zayıf), Tehdit altındaki türler (105-zayıf), Orman örtüsü değişikliği (40-iyi), Atık su arıtma oranı (43-iyi) ve Balık stok durumu (84-orta) şeklindedir.

\section{Seyahat ve Turizm Rekabetçilik Endeksi (TTCI) Altyapı Faktörünün Değerlendirmesi}

TTCI 2019 yılı raporuna göre "Altyapı" faktörünü oluşturan alt faktörler; Hava Taşımacıllğ̆l, Kara Ulaşımı ve Bağlantıları ile Turistik Hizmetler şeklindedir. Altyapı faktörü bir ülkedeki fiziksel altyapının kullanılabilirliğini ve kalitesini değerlendirmektedir (WEF, 2019). Tablo 4'de 2019 yılı TTCI raporundaki Altyapı faktörünü oluşturan alt faktörlerin beşli grup ölçeğine göre Türkiye'nin sıralamaları ve yer aldığı gruplar sunulmaktadır. Bu faktörde Türkiye'nin genel faktör sıralaması 38'inci sırada olup “İyi” düzeyde bir görünüm sergilemiştir.

Tablo 4. TTCI 2019 Yılı Altyapı Faktörüne İlişkin Türkiye Sıralamaları

\begin{tabular}{|c|c|c|c|c|c|}
\hline Faktörler & $\begin{array}{l}\text { Çok iyi } \\
(1-30 . \\
\text { sira) }\end{array}$ & $\begin{array}{c}\text { İyi } \\
\text { (31-60. sira) }\end{array}$ & $\begin{array}{c}\text { Orta } \\
(61-90 . \text { sira })\end{array}$ & $\begin{array}{c}\text { Zayıf } \\
(91-120 . \text { sira) }\end{array}$ & $\begin{array}{c}\text { Çok Zayıf } \\
(121-140 . \text { sıra) }\end{array}$ \\
\hline $\begin{array}{l}\text { Hava } \\
\text { Taşımacıllı̆̆1 }\end{array}$ & $20(4.7)$ & & & & \\
\hline $\begin{array}{l}\text { Kara Ulaşımı } \\
\text { ve } \\
\text { Bağlantıları }\end{array}$ & & $56(3.6)$ & & & \\
\hline $\begin{array}{l}\text { Turistik } \\
\text { Hizmetler }\end{array}$ & & $37(5.0)$ & & & \\
\hline $\begin{array}{l}\text { Genel Faktör } \\
\text { Siralaması }\end{array}$ & & 38 & & & \\
\hline
\end{tabular}


Hava Taşımacılı̆̆ı: Türkiye, Seyahat ve Turizm Rekabetçilik Endeksi 2019 raporunda 140 ülke arasında "Hava Taşımacılığı" alt faktöründe 4.7 puanla 20'nci sırada "Çok iyi" düzeyde bir görünüm sergilemiştir. Raporda Hava Taşımacılığı alt faktörü kapsamında değerlendirmeye alınan 6 gösterge ile Türkiye'nin bu göstergelerdeki sıralamaları ve performansları; Hava taşımacılığı altyapısının kalitesi (39-iyi), Yurtiçi mevcut koltuk kilometreleri (11-çok iyi), Uluslararası mevcut koltuk kilometreleri (17-çok iyi), Uçak kalkışları (38-iyi), Havaalanı yoğunluğu (80-orta) ve Çalışan havayolu sayısı (13-çok iyi) şeklindedir.

Kara Ulaşımı ve Bağlantıları: Türkiye, Seyahat ve Turizm Rekabetçilik Endeksi 2019 raporunda 140 ülke arasında "Kara Ulaşımı ve Bağlantıları" alt faktöründe 3.6 puanla 56'ncı sırada "İyi" düzeyde bir görünüm sergilemiştir. Raporda Kara Ulaşımı ve Bağlantıları alt faktörü kapsamında değerlendirmeye alınan 7 gösterge ile Türkiye'nin bu göstergelerdeki siralamaları ve performansları; Yolların kalitesi (33-iyi), Yol yoğunluğu (65-orta), Asfalt yol yoğunluğu (48-iyi), Demiryolu altyapısının kalitesi (58-iyi), Demiryolu yoğunluğu (50-iyi), Liman altyapısının kalitesi (52-iyi) ve Kara taşımacılığı verimliliği (54-iyi) şeklindedir.

Türkiye, Seyahat ve Turizm Rekabetçilik Endeksi 2019 raporunda 140 ülke arasında "Turistik Hizmetler" alt faktöründe 5.0 puanla 37'nci sırada "İyi" düzeyde bir görünüm sergilemiştir. Raporda Turistik Hizmetler alt faktörü kapsamında değerlendirmeye alınan 4 gösterge ile Türkiye' nin bu göstergelerdeki sıralamaları ve performansları; Otel oda sayıları (67-orta), Turizm altyapısının kalitesi (13-çok iyi), Büyük araç kiralama şirketlerinin varlığ1 (1-çok iyi) ve ATM sayıları (33-iyi) şeklindedir.

\section{Seyahat ve Turizm Rekabetçilik Endeksi (TTCI) Doğal ve Kültürel Kaynaklar Faktörünün Değerlendirmesi}

TTCI 2019 y1lı raporuna göre "Doğal ve Kültürel Kaynaklar" fakörünü oluşturan alt faktörler; Doğal Kaynaklar ile Kültürel Kaynaklar ve İş Seyahati şeklindedir. Burada yer alan faktörler seyahatlerin ana sebeplerini oluşturmaktadır (WEF, 2019). Tablo 5'de 2019 yılı TTCI raporundaki Doğal ve Kültürel Kaynaklar faktörünü oluşturan alt faktörlerin beşli grup ölçeğine göre Türkiye'nin sıralamaları ve yer aldığı gruplar sunulmaktadır. Bu faktörde Türkiye'nin genel faktör sıralaması 27'nci sırada olup "İyi” düzeyde bir görünüm sergilemiştir.

Tablo 5. TTCI 2019 Yılı Doğal ve Kültürel Kaynaklar Faktörüne İlişkin Türkiye Sıralamaları

\begin{tabular}{|c|c|c|c|c|c|}
\hline Faktörler & \begin{tabular}{c}
\multicolumn{2}{c}{ Çok iyi } \\
$(1-30 . \quad$ sıra $)$
\end{tabular} & $\begin{array}{c}\text { İyi } \\
\text { (31-60. sira) }\end{array}$ & $\begin{array}{c}\text { Orta } \\
(61-90 . \text { sira })\end{array}$ & $\begin{array}{c}\text { Zayıf } \\
\text { (91-120. sira) }\end{array}$ & $\begin{array}{c}\text { Çok Zayıf } \\
\text { (121-140. sıra) }\end{array}$ \\
\hline $\begin{array}{l}\text { Doğal } \\
\text { Kaynaklar }\end{array}$ & & & $77(2.8)$ & & \\
\hline $\begin{array}{l}\text { Kültürel } \\
\text { Kaynaklar ve } \\
\text { İş Seyahati }\end{array}$ & $17(3.8)$ & & & & \\
\hline $\begin{array}{l}\text { Genel Faktör } \\
\text { Sıralaması }\end{array}$ & 27 & & & & \\
\hline
\end{tabular}

Doğal Kaynaklar: Türkiye, Seyahat ve Turizm Rekabetçilik Endeksi 2019 raporunda 140 ülke arasında "Doğal Kaynaklar" alt faktöründe 2.8 puanla 77'nci sırada “Orta” düzeyde bir görünüm sergilemiştir. Raporda Doğal Kaynaklar alt faktörü kapsamında değerlendirmeye alınan 5 gösterge ile Türkiye'nin bu göstergelerdeki sıralamaları ve performansları; Dünya Mirası olan doğal 
sitelerin sayısı (50-iyi), Toplam bilinen türler (68-orta), Toplam korunan alanların oranı (137-çok zayıf), Doğal turizm dijital talebi (30-iyi) ve Doğal varlıkların çekiciliği (87-orta) şeklindedir.

Kültürel Kaynaklar ve Işs Seyahati: Türkiye, Seyahat ve Turizm Rekabetçilik Endeksi 2019 raporunda 140 ülke arasında "Kültürel Kaynaklar ve İş Seyahati" alt faktöründe 3.8 puanla 17'nci sırada "Çok iyi" düzeyde bir görünüm sergilemiştir. Raporda Kültürel Kaynaklar ve İş Seyahati alt faktörü kapsamında değerlendirmeye alınan 5 gösterge ile Türkiye'nin bu göstergelerdeki sıralamaları ve performansları; Dünya Mirası kültürel sitelerin sayısı (11-çok iyi), Sözlü ve somut olmayan kültürel miras (5-çok iyi), Spor stadyumları (18-çok iyi), Uluslararası dernek toplantılarının sayısı (34-iyi) ile Kültür ve eğlence turizmi dijital talebi (27-çok iyi) şeklindedir.

\section{Seyahat ve Turizm Rekabetçilik Endeksi (TTCI) 2015, 2017 ve 2019 Türkiye Sıralamalarına İlişkin Genel Değerlendirme}

TTCI raporları kapsaminda 2015 yılında 141 ülke, 2017'de 136 ve 2019'da 140 ülke endekste değerlendirilmiştir. Tablo 6 ' da dört ana faktör ve on dört alt faktöre göre Türkiye' nin ilgili yıllara ilişkin sıralamaları yer almaktadır.

Tablo 6. TTCI 2015, 2017 ve 2019 Yıllarına İlişkin Türkiye Sıralamaları

\begin{tabular}{|c|c|c|c|c|}
\hline Faktörler & Alt Faktörler & 2015/141 ülke & 2017/136 ülke & 2019/140 ülke \\
\hline \multirow{5}{*}{$\begin{array}{l}\text { Çevresel } \\
\text { Faktörler }\end{array}$} & İş Çevresi & 59 & $63(-4)$ & $71(-8)$ \\
\hline & $\begin{array}{l}\text { Emniyet ve } \\
\text { Güvenlik }\end{array}$ & 121 & $116(+5)$ & $125(-9)$ \\
\hline & Sağlık ve Hijyen & 63 & $64(-1)$ & $65(-1)$ \\
\hline & $\begin{array}{c}\text { İnsan Kaynakları ve } \\
\text { İş Gücü Piyasası }\end{array}$ & 88 & $94(-6)$ & $97(-3)$ \\
\hline & $\begin{array}{c}\text { Bilişim } \\
\text { Teknolojilerinde } \\
\text { Hizlılık }\end{array}$ & 68 & $72(-4)$ & $71(+1)$ \\
\hline \multirow{4}{*}{$\begin{array}{l}\text { Turizm } \\
\text { Politikalarının } \\
\text { ve Koşullarının } \\
\text { Etkinleştirilmesi }\end{array}$} & $\begin{array}{c}\text { Turizmin } \\
\text { Önceliklendirilmesi }\end{array}$ & 83 & $87(-4)$ & $39(+48)$ \\
\hline & Uluslararası Açıklık & 61 & $50(+11)$ & $52(-2)$ \\
\hline & Fiyat Rekabet Gücü & 94 & $70(+22)$ & $48(+22)$ \\
\hline & $\begin{array}{c}\text { Çevresel } \\
\text { Sürdürülebilirlik }\end{array}$ & 95 & $112(-7)$ & $126(-14)$ \\
\hline \multirow{3}{*}{ Altyapı } & $\begin{array}{c}\text { Hava Taşımacılığı } \\
\text { Altyapısı }\end{array}$ & 16 & $14(+2)$ & $20(-6)$ \\
\hline & $\begin{array}{l}\text { Kara Ulaşımı ve } \\
\text { Bağlantıları }\end{array}$ & 54 & 54 & $56(-2)$ \\
\hline & $\begin{array}{c}\text { Turistik Hizmet } \\
\text { Altyapısı }\end{array}$ & 38 & $42(-4)$ & $37(+5)$ \\
\hline \multirow{2}{*}{$\begin{array}{l}\text { Doğal ve } \\
\text { Kültürel } \\
\text { Kaynaklar }\end{array}$} & Doğal Kaynaklar & 73 & $70(+3)$ & $77(-7)$ \\
\hline & $\begin{array}{c}\text { Kültürel Kaynaklar } \\
\text { ve İş Seyahati }\end{array}$ & 16 & 16 & $17(-1)$ \\
\hline
\end{tabular}

Kaynak: (WEF, 2015; WEF, 2017; WEF, 2019) 
Tablo 6' da yer alan sıralama renklerine ilişkin olarak yeşil renk bir önceki yıla ilişkin sıralamanın yükseldiğini, kırmızı renk sıralamanın düştüğünü ve mavi renk ise sıralamada herhangi bir değişiklik olmadığını göstermektedir. Ayrıca sıralamaların yanında parantez içerisinde bir önceki yıla ilişkin yükseliş veya düşüşlerin basamak değişim derecesi + ve - yönleriyle belirtilmiştir. Buna göre en fazla gelişim ivmesi gösteren alt faktör 48 basamak yükseliş derecesiyle 2019 yılında Turizmin Önceliklendirilmesi faktörüne aittir. Bu faktörü son iki dönemde 22 'şer basamak derecesi ile yükseliş gösteren Fiyat Rekabet Gücü faktörü izlemektedir. Ayrıca bu faktör ardışık olarak son iki dönemde yükseliş gösteren tek faktördür. Buna karşın 2019 yılında en fazla düşüşlerin 14 derece ile Çevresel Sürdürülebilirlik, 9 derece ile Emniyet ve Güvenlik ve 8 derece ile İş Çevresi faktörlerinde oluştuğu görülmektedir. Bu faktörleri 7 düşüş derecesiyle Doğal Kaynaklar ve 6 düşüş derecesiyle Hava Taşımacılığı Altyapısı faktörleri izlemektedir. Ayrıca son iki dönemde de ardışık olarak düşme ivmesine sahip faktörlere bakıldığında; Çevresel Sürdürülebilirlik faktörünün 2017' de 7 ve 2019'da 14 derece olmak üzere toplamda 21 basamak, Iş̧ Çevresi faktörünün 2017' de 4 ve 2019'da 8 derece olmak üzere 12 basamak, İnsan Kaynakları ve İş Gücü Piyasası faktörünün 2017' de 6 ve 2019'da 3 derece olmak üzere 9 basamak ile Sağllk ve Hijyen faktörünün 2017'de 1 ve 2019' da 1 derece olmak üzere toplamda 2 basamak derecesi biçiminde geriledikleri tespit edilmiştir.

\section{SONUÇ, TARTIŞMA ve ÖNERILER}

TTCI 2019 raporuna göre Türkiye'nin, Çevresel Sürdürülebilirlik (126) ile Emniyet ve Güvenlik (125) alt faktörleri bakımından "çok zayıf" bir rekabetçi pozisyonda olduğu görülmektedir. İnsan Kaynakları ve İş Gücü Piyasası (97) alt faktörü açısından ise "zayıf" bir rekabetçi pozisyondadır. Doğal Kaynaklar (77), İş Çevresi (71), Biliş̧im Teknolojilerinde Hızlılık (71) ile Sağlık ve Hijyen (65) alt faktörleri bakımından "orta", Kara Ulaşımı ve Bağlantıları (56), Uluslararası Açıklık (52), Fiyat Rekabet Gücü (48), Turizmin Önceliklendirilmesi (39) ve Turistik Hizmet Altyapısı (37) alt faktörleri bakımından "iyi" bir rekabetçi pozisyondadır. "Çok iyi" rekabetçi pozisyonda yer aldığı alt faktörler ise, Hava Taşımacılığı Altyapısı (20) ile Kültürel Kaynaklar ve İş Seyahati (17) biçimindedir. Araştırma kapsamında TTCI 2019 raporunda yer alan ilgili 14 alt faktöre ilişkin Türkiye'nin mevcut durumuna yönelik bilgiler aşağıda sunulmaktadır.

İş Çevresi: Yurt içine gelen doğrudan yatırımların (FDI) ve yurt dışına giden doğrudan yatırımların (ODI) nasıl bir biçimde seyrettiği ODI/FDI oranıla izlenebilmektedir. İlgili oran basit bir bölme işlemiyle elde edilebiliyor olsa da Türkiye'nin yatırım ortamına yönelik temel bir gösterge olarak ele alınmalıdır. Yatırımcıların kararlarını etkileyen hukuki düzenlemeler, vergi yükleri, iç pazarın cazibesi, iş gücünün beceri seti ve iş gücü maliyetleri ile ekonomik-siyasi istikrar gibi çeşitli unsurlar bulunmaktadır. Örnek olarak nitelikli iş gücüne ulaşmada yaşanan güçlükler ve iş gücü maliyetlerindeki artış, yatırımcıları katma değeri daha yüksek ve daha düşük maliyetlerle üretim yapabilecekleri alanlara taşımalarına sebep olabilmektedir. Buna bağlı olarak işveren maliyetlerindeki düşüş, mesleki eğitimde kalitenin artışı ve mevzuata dayalı problemlerin kaldırılmasına ilişkin faaliyetler, yurt içindeki yerleşik yatırımcıların mevcut yatırımlarını korumalarını ve diğer yeni yatırımlara geçebilmelerini kolaylaştırmanın yanında yabancı yatırımcılar için de Türkiye'nin tercih edilmesini sağlayabilmektedir. Bunlarla birlikte uluslararası derecelendirme kuruluşlarının da ülkeler ve finansal kuruluşlar için oluşturdukları notlar özellikle yabancı yatırımcıların bir ülkede yapacağı yatırım kararlarını etkileyen önemli göstergelerdendir (TEPAV, 2019). Ekonomideki güven ortamını iyileştiren, sürdürülebilir büyümeyi destekleyen, hukuk sisteminde normalleşmeyi sağlayan ve banka bilançolarını güçlendiren bir politika setinin uygulanması Türkiye'nin kredi notlarının yükselmesini ve yabancı yatırımcıların Türkiye'ye yönelik yatırım kararlarının artmasını sağlayacaktır. 
Çok sayıda dünya ülkesi "Girişimci Vizesi" adı altında uygulamalar devreye sokarak girişimcilere çok sayıda fırsatlar sunmaktadırlar. Ülkeler, çeşitli katılım koşullarını içeren ilgili vize programlarıyla özellikle yüksek teknoloji yatırımlarını kendilerine çekme gayreti içerisindedirler. Girişimcilik vizeleri, vatandaşlık hakkı tanınmamış kimselerin, yeni bir işe başlama amacıyla belirli bir zaman aralığı için başka bir ülkeye yerleşmelerine ve çalışmalarına bu ülkede devam etmelerine olanak sağlayan bir vize türüdür. Birçok gelişmiş ve gelişmekte olan ülke girişimci vizelerini, özellikle inovatif girişimleri ve nitelikli iş gücünü kendi ülkelerine çekebilmek için bir fırsat olarak görmekte ve kendi ülkelerini bu yatırımlar için daha cazibeli hale getirebilmede farklı programlar geliştirmektedir (Aytaç, 2016). Türkiye gibi nitelikli iş gücü sıkıntısı çeken bir ülke için yabancı girişimcileri desteklemek ve buna uygun bir vize programı oluşturmak daha fazla geciktirilmemesi gereken önemli bir adım olarak değerlendirilebilir.

Türkiye'de turizmcilerin genel vergi yükümlülükleri; kurumlar vergisinde $\% 20$, gelir vergisinde $\%$ 15-35, kar dağıtımı stopajında \% 15, içkide ÖTV \% 50'nin üzerinde, katma değer vergisinde \% 8-18, emlak vergisinde \%o 1-6'nın yanı sıra ödemenin türüne göre değişen gelir vergisi stopajı, işyerine göre değişen çevre temizlik vergisi, işletme türüne göre değişen eğlence vergisi, ilanın ebadına ve belediyesine göre değişen reklam ve ilan vergisi, işsizlik sigortası ve SSK primleri, taşıtın özelliğine göre değişen motorlu taşıtlar vergisi, harçlar, damga vergisi, gider vergisi, \% 3'e kadar ciro üzerinden irtifak hakkı ve diğer ödemeler biçiminde sıralandığında turizmdeki vergi yükü görülebilmektedir (Tezcan vd., 2008; Göral, 2017).

Katma Değer Vergisine (KDV) ilişkin 01.01.2008'den itibaren sadece oda, kahvaltı dahil oda, yarım ile tam pansiyon ve her şey dahil konaklamalarda KDV oranı \% 18'den \% 8 KDV oranına geçiş uygulamaya alınmıştır. Otel içinde veya bağımsız lokanta ve restoranlarda sunulan yiyecekler ve alkolsüz içecekler \% 8, alkollü içecekler ise \% 18 oranında KDV'ye tabi tutulmuştur. Dans okulu, bar ve gazino gibi yerlerde ise sunulan hizmetlere ilişkin KDV ise \% 18 şeklinde kalmıştır (Bülbül, 2012). Bunlara bağlı olarak KDV oranlarında 2008 yılında uygulanan bu indirimlerle birlikte Türkiye turizminde daha olumlu bir seviyeye ulaşılması sağlanmıştır.

Tüm dünyayı etkisine alan Covid-19 salgını kapsamında işletmelerin mevcut yapılarını sürdürebilmeleri için vergisel tedbirler hükümetin ve yerel yönetimlerin uyguladıkları yaklaşımların başında gelmektedir. Bu doğrultuda kuruluş ve işletmelerin yükümlülüklerinde olan vergi ve sigorta gibi ödemelerinin miktarı düşürülmekte veya ödemelerin vadeleri ertelenmektedir. Finansal duruma ve ekonomik kapasiteye göre vergisel tedbirler kısmi vergi türleri ile sınırlı kalabildiği gibi tüm vergi türlerinde de uygulanabilmektedir. Vergisel önlemlere yönelik uygulamaların başında katma değer vergisi oranları üzerinde geçici süreyle yapılan indirimler gelmektedir. Bununla birlikte vergi artışına gidilmeme veya ödenen vergilere ilişkin iade uygulamalarıyla işletmeler desteklenmektedir (Çakır ve Barakazı, 2020). Bu bağlamda örneğin; tiyatro, bale, opera, sinema ve müze ziyaret ücretleriyle birlikte turizm endüstrisinin en önemli harcamasını oluşturan yeme-içme ve konaklama hizmetlerinde KDV oranları \% 8'den \% 1'e çekilmiştir. Benzer şekilde konser, konferans, seminer, kongre, lunapark ve fuar giriş ücretleri ile işyeri kiraları ve yolcu taşımacılığında KDV oranları \% 18'den \% 8'e düşürülmüştür (Turizm Günlüğü, 2020). Tüm bu uygulamaların Covid-19 salgını süresince kısitlamaların kalktığ1 dönemlerde turizm endüstrisinde faaliyet gösteren işletmelerin rahat bir nefes almasını kolaylaştırdığı söylenebilir.

İşletmeler, faaliyetlerine başlayabilmede genel işyeri açma ruhsatı ve sektör ruhsatlarını edinmek durumundadırlar. Örneğin otel işletmeleri faaliyetlerine başlamadan önce bulunduğu belediyeden işyeri açma ruhsatlarını çıkartmak zorundadırlar. Ayrıca Turizm Bakanlığı tarafından da ruhsatlandırılmaları gerekmektedir. Bununla birlikte Turizm İşletme Belgeli işletmeleri ilgili işletme belgesine ilişkin düzenlemeleri konu alan hususlara yönelik sadece Kültür ve Turizm Bakanlığı denetlemektedir. 2634 sayılı Turizm Teşvik Kanunu kapsamındaki 
"Kültür ve Turizm gelişim alanlarında Çevresel Etki Değerlendirmesi olumlu veya gerekli değildir." kararı verilen yatırımlar için çalışma ve işyeri açma ruhsatı, başka bir işleme gerek duyulmaksızın on beş gün içerisinde yetkili idareler tarafından verilmektedir (Gündüzöz, 2010).

Girişimcilerin dünya genelinde iş yapma çevresine yönelik 190 ülke ekonomisini değerlendiren “İş Yapma Kolaylığı Endeksi” 2019 yılı raporuna göre; bir önceki yıl 75,3 puanla 43'üncü sırada bulunan Türkiye, 76,8 puan ile en kolay iş yapma çevresine sahip 33'üncü ülke konumuna yükselmiştir (Dünya Bankası, 2019).

Emniyet ve Güvenlik: 2014 yılında Türkiye' de başarılı bir yıl geçiren turizm endüstrisi, bu yıldan itibaren gerileme sürecine girmiştir. 2015 yılında düşük oranda da olsa turizm gelirleri açısından gerileyen turizm, 2016 yılında tarihi düşüşlerinden birini yaşamıştır. Sektörde 2016 yılı oldukça zorlu geçmiş ve kalkışma, terör olayları gibi çeşitli krizler yaşanmıştır. Irak ve Suriye'deki savaş durumu ve yaşanan terör olayları ilgili dönemlerde Türkiye turizminin düşüşündeki en önemli etkenler arasında gösterilmektedir. Bu etkenler sonucu Türkiye'nin yıllık büyüme rakamları beklentilerin altında gerçekleşmiştir (T.C. Kalkınma Bakanlığı, 2018a). Her ne kadar 2015 ve 2016 yıllarında ülkemizde yaşanan terör olaylarının 2019 yılı raporunda emniyet ve güvenlik alt faktöründe çok zayıf görünümünden söz edilse de, Türkiye'nin hem içeride hem de dışarıdaki komşu ülkeleri ve sınır hattında gerçekleştirdiği başarılı operasyonları dolayısıyla emniyet ve güvenliğin önemli düzeyde sağlanması, gelecek raporlarda daha üst sıralarda bir görünüm sergilemesini sağlayabilecektir.

Sağllk ve Hijyen: Sağlık hizmetlerine erişimin; acil sağlık hizmetleri erişimi, hastaneye yatış süresi, ayakta bakım, ilaç tüketimi, evde bakım, laboratuvar hizmetleri kullanımı gibi birçok göstergesi vardır ve tek bir gösterge ile izahı zordur. Ancak hekim konsültasyonlarına betimleyici bir şekilde bakmak erişim ve kullanım hakkında kabaca bir fikir verebilir. OECD verilerine göre 2005-2019 yılları arasında Türkiye'de hekim başına düşen konsültasyonlara göre 2005 yılında yaklaşık 4,5 olan kişi başına yıllık konsültasyon sayısı, 2019 yılında yaklaşık 9 olmuştur (Demir, 2020: 23). Ayrıca Türkiye sağlık turizmi altyapısı açısından rekabetçi bir konuma sahip olup; 2018 yılı itibariyle Uluslararası Birleşik Komisyonu (JCI) ile uluslararası standartlarda akredite olmuş 46 adet sağlık kuruluşuna sahiptir (T.C. Kalkınma Bakanlığı, 2018a:16).

İnsan Kaynakları ve İşgücü Piyasası: Türkiye' de turizm endüstrisi 54 sektörü doğrudan, 185 sektörü de dolaylı yönden etkilemekte ve bu yönüyle Türkiye'nin en çok döviz getiren ve en rekabetçi endüstrilerinden biri konumundadır. Toplamda makroekonomik olarak \% 2,5'lik katma değeri ve 96 milyar \$ düzeyinde hasıla etkisiyle en yüksek gelişme potansiyeline sahip endüstrilerinden biridir. Ayrıca \% 10 oranı ile ithalat bağımlılığında en düşük endüstriler içerisindedir. Türkiye'deki işletmelerin yaklaşık \% 10'u turizm endüstrisinde faaliyettedir. Gerçekleştirilen maddi yatırımların \% 4'ü ve ücret ödemelerinin \% 5'i turizmde yapılmaktadır. Turizm endüstrisi, Türkiye'de istihdam oluşturmada altyapı endüstrisinden sonra en yaygın ikinci endüstridir (Bahar ve Çelik, 2020:126).

Türkiye'nin turizme yönelik istihdamında karşılaşılan ciddi sorunlar yer almaktadır. Turizm endüstrisinde ikili bir iş gücü niteliği ve yapısı bulunmaktadır. Bununla birlikte nitelikli iş gücünü benimseyen işletmeler az sayıdadır ve bu işletmeler iş gücünde mesleki yeterliliği önemsemekte ve nispeten nitelikli çalışan çalıştırmaktadır. Buna karşın endüstri genelinde niteliksiz genç çalışanlar istihdam edilmektedir. Buna ilave olarak kadınların istihdamı bakımından önemli bir potansiyele sahip olan Türkiye turizminde sezonluk ve kayıt dışı istihdam, aşırı çalışma süreleri ve yüksek iş gücü devri gibi problemlerden dolayı nitelikli iş gücü ve kadın istihdamında ciddi sorunlarla karşlaş̧labilmektedir (Göral, 2017:149).

Bilişim Teknolojilerinde Hızlılık: Bilişim teknolojileri, iletişim ve bilgisayar teknolojilerinin beraber kullanılmasıyla oluşturulan sistemlerdir. Bilgilerin toplanmasını, depolanmasını, işlenmesini, 
ağlar aracılığıyla iletilmesini sağlayan bilgisayar ve iletişim teknolojilerini de içeren bütün teknolojileri kapsamaktadır. Bu teknolojilerde, veri iletimi ve mikro elektronikle birlikte bilgi ağları, yazılımlar, mobil telefonlar, bilgisayarlar, televizyon, videoteks, faks cihazları ve çevrimiçi bütün veri tabanları bulunmaktadır. İletişim teknolojileri ile mesajlar hızlı bir biçimde iletilmekte, bilgisayar teknolojileriyle ise hemen her alanda bilgi işleme ve hesaplama yeteneklerinin sayesinde bu işlemler milyonlarca kez arttırılarak kullanılabilmektedir (Özhavzalı \& Erduran, 2019:145).

Küresel Bilgi Teknolojileri 2016 raporuna göre Türkiye, 142 ülke arasında 52'nci siradadır. Türkiye bilim teknolojileri pazarı, 2012 yılında 30 milyar \$ büyüklüğe erişmiştir. Aynı yıl telekom pazarı 23 milyar \$ ve yazılım, donanım ve bilişim hizmetleri alanları 7 milyar \$ büyüklüğe ulaşmıştır. 2016 yılında bilişim sektörü 9,8 milyar \$, iletişim sektörü ise 20,4 milyar \$ büyüklüğe ve toplamda da 31,2 milyar \$ seviyesine ulaşmıştır (T.C. Kalkınma Bakanlığı, 2018b).

Türkiye'de güçlü ve etkin bir bilişim teknolojileri ağının oluşturulmasında insan kaynaklarının bilgi toplumundaki ihtiyaçlarına yönelik organizasyonu, toplumun çeşitli kesimlerinin iletişim ve bilgi teknolojilerinden istifade etkinliğinin arttırılması ve eşitsizliklerin azaltılması, kullanıcı güveninin ve bilgi güvenliğinin tesisi, farklı toplumsal sorunlarla mücadelede iletişim ve bilgi teknolojileri desteğiyle üst düzeyde yenilikçi çözümlerden yararlanılması, geniş bant altyapı sistemlerinin sağlıklı bir biçimde yapılanması, kamu hizmetlerinde kullanıcı odaklı etkinliğin sağlanması ve e-ticaret ile internet girişimciliğinin ekonomik kalkınmada katkı sağlayacak bir ekosisteme dönüştürülmesi kalkınmada öncelikli hedefleri oluşturmaktadır (T.C. Kalkınma Bakanlığı, 2018b). Bu gelişmelere bağlı olarak internet ağında en hızlı ve etkin iletişimi sağlamakta olan fiber altyapı açısından 2019 yılı üçüncü çeyreğinde $371.304 \mathrm{~km}$. olan fiber altyapı uzunluğu, 2020 yılı üçüncü çeyreğinde \% 11'lik bir artış oranıyla 413.309 km.'ye ulaşmıştır (Türkiye Bilişim Derneği, 2020).

Turizmin Önceliklendirilmesi: On Birinci Kalkınma Planında öncelikli gelişme alanları tarım, savunma sanayi ve turizm olarak belirlenmiştir. Cumhurbaşkanlığı Hükümet Sistemi'nin ilk kalkınma planı olan ve Cumhurbaşkanlığ Strateji ve Bütçe Başkanlığı tarafınca hazırlanan 20192023 On Birinci Kalkınma Planı, 15 yıllık bir stratejinin ilk beş yılına ait dilimini kapsamaktadır. Her alanda verimlilik artışını ve rekabetçiliği sağlamayı amaçlayan On Birinci Kalkınma Planı'nın vizyonu ise daha çok değer üreterek daha adil paylaşan, müreffeh ve güçlü bir Türkiye inşa etmektir. On Birinci Kalkınma Planı'nda öncelikli sektörlere ilaveten öncelikli gelişme alanları arasında yer alan turizm endüstrisiyle ilgili belirlenen temel hedef, turizm hizmetlerinde çeşitlilik ve niteliği arttırarak turizmin ekonomik ve sosyal katkısını arttırmaktır (T.C. Kalkınma Bakanlığı, 2018a).

Turizm endüstrisinin On Birinci Kalkınma Planı'na ilişkin amacı, gelişen teknolojik ilerlemelerle değişen tüketici eğilimlerine yönelik turizmin geliştirilerek çeşitlendirilmesi, hizmet kalitesinin arttırılması, sezon sürelerinin uzatılması, daha yüksek harcama eğiliminde olan ziyaretçilerin Türkiye'ye çekilmesi, konaklama süreleri ve konaklama harici harcamaların arttırılması, her bir destinasyon özeline odaklı anlayışla turizmde dönüşümün sağlanması ve kullanma-koruma gözetilerek sosyal ve ekonomik kalkınmaya katkı oluşturulması biçiminde ifade edilmektedir. Ayrıca mevzuat düzenlemeleriyle beklentilere uygun bir yasal zeminin oluşturulması, yatırımların desteklenmesi, sektörel maliyetlerin azaltılması ve teşvik uygulamalarının yaygınlaştırılması da hedefler arasında yer almaktadır. Bu stratejilerin uygulanmasıyla 2023 yılı itibariyle ortalama konaklama süresi ve harcamalarda artışın sağlanması beklenmekte; turizm gelirinin 65 milyar \$ düzeyine, toplam ziyaretçi sayısının ise 75 milyona ulaşması hedeflenmektedir (Batuhan, 2020:81). Bununla birlikte Aralık 2020'de TBMM'de Kültür ve Turizm Bakanlığı'nın 2021 bütçesi kabul edilmiştir. TBMM'de yapılan bütçe görüşmelerinde, 2020 yılında 5 milyar 127 milyon lira bütçe tahsis edilen Kültür ve Turizm Bakanlığı'nın 2021 
bütçesi, yüzde 33'ün üstünde arttırılarak 6 milyar 828 milyon liraya çıkarılmıştır. Böylelikle, Bakanlığın bütçesi 2020 yılına göre 1,7 milyar lira arttırılmıştır (Turizm Güncel, 2020).

Uluslararası Açıklık: Türkiye, günümüzde G-20 ülkeleri olarak bilinen ülkeler içinde yer almakta ve dünyanın 16'ncı, Avrupa'nın ise 6'ncı büyük ekonomisidir. Ayrıca dünyada öne çıan çok sayıda kurum ve kuruluşa da üyedir (Doğan, 2015:308). Türkiye 2019 yılında dünyada en çok turist ağırlayan 6'ncı ülkedir (UNWTO, 2020). Ancak turizmden elde edilen gelir halen istenilen düzeyde değildir. Bunun için devletin turizm endüstrisinde gerçekleştirilecek tüm faaliyetleri teşvik edici politikalar üretmesi gerekmektedir (Pata, 2020:164). Turistlere sunulan hizmetler çeşitlendirilmeli, konaklama ve ulaşım bakımından gelişmiş olanaklar ülke genelinde sağlanmall, turistlerin kendilerini yüksek seviyede güvenli hissedebileceği ortamlar genişletilmelidir.

Fiyat Rekabet Gücü: Ülkeler ürettikleri mal ve hizmetleri, fiyatları açısından çekici hale getirebilmek için uluslararası piyasalarda milli para değerlerini ayarlama yoluna gidebilmektedirler. Bir ülkenin milli parasının başka ülkelerin paralarına kıyasla değerinin düşürülmesi biçimindeki bu işlem "Devalüasyon" olarak adlandırılmaktadır. Bu durumda yabancı ziyaretçi sayısı ve ziyaretçi başına düşen ortalama harcama miktarlarında artışlar sağlanabilir. Fakat turizm endüstrisinde bu tür kur ayarlamaları her zaman olumlu etkiler sağlamayabilir. Ülkede döviz kurunun yüksek olması ülkenin dış turizmini olumlu yönde etkileyen önemli faktörler arasındadır. Kısa dönemlerde fiyatların etkinliği turizm talebi üzerinde oldukça yüksek olabilmektedir. Belirli bir bütçeye sahip seyahat kararı alan turistler döviz kuru yüksekliği sebebiyle daha ucuz hale dönüşen ülkeleri tercih edebileceklerdir. Bu durumda yabancı turistler için bir tüketici rantı oluşacağından, yabancı turistler seyahat planına ve bütçesine bağlı olarak tasarladığı turizm mal ve hizmetlerini ödemeyi planladığı fiyattan daha cazip fiyatlar ile elde etme olanağına sahip olabilecekler ve bunun sonucunda daha uzun süreler ve daha çok sayıda avantaj ile tatil yapılabilmesine fırsat tanıyan ülkeleri tercih edebileceklerdir (Karadă̆ ve Bağcl, 2019:451).

Dünya turist başı ortalama harcaması 2018 yılında yaklaşık 1.100 \$'dır. 650 \$ ortalama turist harcaması ile (2019 yılı ortalaması 666 \$) Türkiye halen ucuz ülke sınıfındadır. Turizm arzında doğal kaynaklara yönelik aşırı kullanım odaklı kitlesel turizm ile her şey dahil sisteminin ön planda olması ve bu turizm türünün çeşitli politikalar ile desteklenmeye devam etmesi bu durumun en temel nedenlerinden biridir. Bu sorunun kalıcı hale gelmesinde turizme yönelik makro planların yapılamaması, pazarın çeşitlendirilememesi ve alternatif turizm pazarlarının oluşturulamaması etkilidir (Sar1, 2019:6). Bununla birlikte Covid-19 salgını sebebiyle turizm ürün ve hizmetlerinde uygulanan tedbirlere bağlı olarak 2020 yılı fiyatlarında bir artış oluştuğunu söylemek mümkündür. 2020 yılı turizm istatistikleri incelendiğinde ortalama turist harcamasının bir önceki yıla oranla \% 14'ün üzerine ulaşarak 762 \$ seviyesine çıkması bunu doğrular niteliktedir.

Çevresel Sürdürülebilirlik: Turizmin ekonomik bir endüstriye dönüşmesi, giderek gelişmesi ve bu gelişmenin sürekli devam edeceğine ilişkin görüşler zamanla kültürel, sosyal ve çevresel etkilerinin daha çok dikkat çekmesine sebep olmuştur. Turizm arzındaki artışa bağlı olarak tüketilen kaynaklar da artmaktadır. Uluslararası düzeyde sürdürülebilirliğin önem kazanmasıyla "Sürdürülebilir Turizm" gündemi yaygınlaşmıştır. Ayrıca yeni destinasyonlar keşfeden kitle turizminin artışıyla birlikte literatürde sürdürülebilir turizm konusu hızla gelişmiştir (Sarı, 2019).

Dünya genelinde değişen ve dönüşen ziyaretçi davranışları incelendiğinde, sağlıklı ve sürdürülebilir hayat tarzını benimseyenlerin sayısı giderek artmaktadır. Destinasyonlara yönelik çevresel duyarlılığa daha çok önem verilmesinin başlanmasıyla turizm endüstrisindeki 
paydaşların çevre duyarlılığı ve sürdürülebilir turizm odaklı faaliyetlere önem vermeye çalıştıkları görülmektedir. Türkiye' de Yeşil Anahtar, Yeşil Yıldız, Green Globe, EU Eco-label gibi programlara dahil olarak enerji tüketimlerini en aza indiren uygulamaları benimseyen paydaşların sayısı hızla artmaktadır (T.C. Kültür ve Turizm Bakanlığı, 2018).

Hava Taşımacılığı: Türkiye'de havayolu sektörü 2920 sayı ve 14.10 .1983 tarihli Sivil Havacılık Kanunu'nun yürürlüğe girmesiyle birlikte gelişimini hızlandırmıştır. 1985 yılından sonra havayolu firmalarının sayısı yükselirken, filo kapasitelerinde ve pazar paylarında ciddi artışlar meydana gelmiştir. Bu dönemlerde firmalar toplamda 52 uçak ve 10.558 koltuk kapasitesiyle 27 ülkeye uçuş gerçekleştirmişlerdir (Sönmez ve Eroğlu, 2021:55). 2008 yılında 270 olan uçak sayısı, 2016 yılında iki katına ulaşarak 540'a yükselmiştir ve bu gelişim artarak devam etmektedir. 2016 yılında sektörde 100.336 koltuk kapasitesi ile 50 ülkeye uçuş gerçekleştirilmiştir. Uçulan iç hat nokta sayısı 55, dış hat nokta sayısı ise 286 olmak üzere toplam 341 noktaya uçulmaktadır. 2019 yılında ise uçak sayısı 546, toplam taşınan yolcu sayısı ise 209 milyondur (DHMİ, 2019).

Kara Ulaşımı ve Bağlantıları: Türkiye 2000'li yıllardan itibaren kara ve demir yolları ağının geliştirilmesinde yüksek mesafeler kat etmiştir. 2020 yılı Eylül ayı sonu itibariyle Türkiye'de $34.124 \mathrm{~km}$. (\% 50) il yolu, $31.002 \mathrm{~km}$. (\% 45) devlet yolu ve $3.325 \mathrm{~km}$. (\% 5) otoyol olmak üzere toplam $68.451 \mathrm{~km}$. yol ağına ulaşılmıştır. Bu yol ağının $27.641 \mathrm{~km}$.'si (\% 40) bölünmüş yol biçiminde hizmet vermektedir. Üstyapı kaplaması şeklinde incelendiğinde $26.866 \mathrm{~km}$.'si bitümlü sıcak karışım kaplama, 38.418 km.'si sathi kaplama olup 3.167 km.'si ise diğer (Toprak, Parke, Stabilize vb.) kaplamalardır. Türkiye, dünyada 8'inci, Avrupa'da ise 6'ncı Yüksek Hızlı Tren işleten ülke konumundadır. 2009 yılında başlayan konforlu, hızlı ve modern seyahat dönemi yedi il ve ülke nüfusunun yüzde 40'1na hitap etmektedir. Özellikle 2003 yılından günümüze kadar $1.213 \mathrm{~km}$. yüksek hızlı tren hattı ve $631 \mathrm{~km}$. ilave konvansiyonel hat işletmeye alınarak Türkiye'nin demiryolu ağı Ağustos 2020 itibariyle 12.803 km.'ye yükseltilmiştir. 2019 yılı sonunda Türkiye limanlarına uğrayan kruvaziyer gemi sayısı 344 ve Türkiye limanlarını ziyaret eden kruvaziyer yolcu sayısı ise 301 bin yolcuya ulaşmıştır. Türkiye'nin artan turizm potansiyeliyle birlikte Akdeniz çanağındaki yat turizminden alacağı payın arttırılmasına ilişkin oluşturulan stratejiler yat limanı sayılarını arttırmaktadır (T.C. Ulaştırma ve Altyapı Bakanlığı, 2020).

Turistik Hizmet Altyapısı: Türkiye' de her 100 kişiye düşen tesis oda sayısı 0,5'dir (WEF, 2019). Visa Kart kullanılabilirliği ve otomatik para çekme makinesi (ATM) sayısı turistik hizmet altyapılarının ölçümlemesinde kullanılmaktadır. Türkiye'de Visa Kart kabul eden ve 1 milyon kişiye düşen ATM sayısı 781'dir (WEF, 2019).

Doğal Kaynaklar: 1972 yılında UNESCO’nun kabul ettiği “Dünya Kültürel ve Doğal Mirasın Korunması"na ilişkin sözleşmeyle "Dünya Kültürel ve Doğal Mirası Listesi” oluşturulmuştur. 2019 yılında Azerbaycan'ın ev sahipliği ve başkanlığında Bakü'de 43'üncü oturumu gerçekleştirilen ve "Dünya Mirası Komitesi" tarafından kabul edilen miraslarda dahil olmak üzere listede toplam 1121 miras bulunmaktadır. Bunlardan 213'ü doğal, 869'u kültürel ve 39'u karma (kültürel ve doğal) miraslardır. Listede Türkiye'den 2'si karma ve 16'sı kültürel olmak üzere toplam 18 miras alanı yer almaktadır (UNESCO, 2019).

Türkiye'de, dağılım gösteren flora elementlerinin sayısı neredeyse Avrupa kıtasının bütününde yayılım göstermekte olan bitki türlerinin sayısı kadardır. Türkiye'nin yaklaşık 3000'i endemik toplamda 12.000 civarında bitki taksonuna ev sahipliği yaptığı bilinmektedir. Bununla birlikte, \% 34,4'lük endemizim oranıyla endemik tür çeşitliliği bakımından da Avrupa'daki en zengin ülkelerin başındadır. Endemik bitki türleri çoğunlukla Anadolu'da yaygındır ve özellikle dağlık kısımlarda yoğunlaşmaktadır. Faunayı oluşturan hayvan türleri, biyolojik olarak omurgalı ve omurgasız canlılar olarak sınıflandırılmaktadır. Türkiye'nin omurgalı faunası büyük ölçüde 
çalışılarak ortaya konmuştur. Ülkemizde yaşayan omurgalı türlerin toplam sayısı 1500 civarındadır. Türkiye faunası 170 civarında memeli, 500'e yakın kuş, 130'un üzerinde sürüngen, 30'dan fazla kurbağa, 680'nin üzerinde balık türü içermektedir. Bu canlılardan 16 sürüngen, 37 memeli ve 70'e yakın tatlı su balığ taksonu endemiktir (Seven, 2020).

Türkiye'de 2017 yılı itibariyle, Çevre ve Şehircilik Bakanlığı Tabiat Varlıklarını Koruma Genel Müdürlüğü ile Tarım ve Orman Bakanlığı sorumluluğu altındaki korunan toplam alanları (deniz ve kara) ülke yüzölçümünün \% 8,9'u oranındadır. Korunan toplam alan hesaplamalarında içme suyu havzaları, meralar ve korunan alan haricindeki doğa koruma faaliyeti olarak ayrılmış mera, orman toprağı, taşlık, toplam orman gibi orman alanları dahil değildir. Korunan alanların oranları 2012 yılında \% 7,8, 2014' de \% 7,3 ve 2017' de \% 8,9 seviyelerinde olmuştur. 2014 yılındaki düşüşün temel nedeni 2014 yılında "Sulak Alanlar Yönetmeliği" ndeki değişiklikle birlikte sulak alanlar için tescil sürecinin getirilmesidir. Dünya genel durumu ele alındığında, Dünya Bankası 2017 yılı verilerine göre, dünya denizel ve karasal korunan alanlarının karasal alanına oranı \% 14,3'dür (T.C. Çevre ve Şehircilik Bakanlığı, 2017).

Kültürel Kaynaklar ve İş Seyahati: Dünya Mirası Komitesince belirlenen UNESCO Dünya Mirası Listesinde bir önceki alt faktörde bahsedilen mirasların yanında ilgili listeye girmesi önerilen ancak henüz adaylık aşamaları bitmemiş miraslardan oluşan "Dünya Mirası Geçici Listesi" bulunmaktadır. Asıl listeye başvurulacak olan alanlar, üye ülkeler için ulusal bir envanter niteliğinde olan söz konusu Geçici Liste'den seçilmektedir. UNESCO Dünya Mirası Geçici Listesi'nde 178 üye ülkenin 1740 adet mirası bulunmaktadır. Geçici Liste'de Türkiye'nin 1994 yllında ilki sunulan ve en son 2020 yılında güncellenen biçimiyle 3 doğal, 78 kültürel ve 2 karma mirastan oluşan toplam 83 adet mirası yer almaktadır (UNESCO, 2020). Ayrıca kültürel kaynaklar açısından "UNESCO Yaratıcı Şehirler Ağı” programında dünya genelinde 246 şehir bulunmaktadır. Potansiyel şehirler yedi başlıktan oluşan Tasarım, Zanaat ve Halk Sanatları, Müzik, Gastronomi, Film, Edebiyat ve Medya Sanatları temalarında programa dahil olabilmektedirler. Türkiye'den halihazırda İstanbul (Tasarım), Kütahya (Zanaat ve Halk Sanatları), Kırşehir (Müzik), Gaziantep, Hatay ve Afyonkarahisar (Gastronomi) olmak üzere altı şehrimiz toplamda dört temadan programa dahil olmuşlardır (UNESCO, 2020).

FIFA ve UEFA verilerine göre Türkiye, dünyada son yıllarda en fazla stadyum inşa eden ülkeler listesinde üst sıralarda yer almaktadır. Yapımı tamamlanan ve yenilenen yüksek kapasiteli gelişmiş birçok stadyum ile birlikte toplam 32 stadın seyirci kapasitesi yaklaşık 1 milyondur. Ayrıca yapımı devam eden toplam 123 bin kapasiteli altı stadın 2021 yılında tamamlanmasıyla birlikte 1 milyonun üzerinde seyirci kapasitesine ulaşılacaktır. Bunlara ilave olarak proje aşamasında olan dört stadyumun toplam kapasitesi 69 bin civarındadır. Türkiye'deki toplam spor tesisi sayısı ise 3903, spor salonlarının sayısı 904 ve atletizm pistlerinin sayısı 56 şeklindedir (T.C. Gençlik ve Spor Bakanlığı, 2021).

Uluslararası Kongre ve Toplantı Birliği (ICCA) 2018 Yılı Kongre Turizmi Raporuna göre, Türkiye 55 kongre sayısı ile Dünya genelinde 52'nci sıradadır. Raporda Amerika Birleşik Devletleri 947 kongre sayısıyla ülkeler sıralamasında birinci sırada yer alırken, şehirler sıralamasında Paris 212 kongre sayısıyla birinci sırada yer almaktadır. Şehirler sıralamasında Türkiye'nin önemli kongre şehirlerinden olan İstanbul 33 kongreyle 84'üncü sırada ve Antalya 12 kongre ile 225'inci siradadır (ICCA, 2019).

Türkiye'nin rekabetçiliğini değerlendirmede bu araştırma ile aynı metodolojiye sahip 2015 yılı TTCI verilerini esas alarak ortaya konan araştırma sonuçlarına (Göral, 2017) ilişkin ana faktörler kıyaslanmıştır. Buna göre; Türkiye'nin 2015 yılı araştırma verilerinde "orta" bir görünümde olduğu belirlenen "Çevresel Faktörler"in 2019 yılında bu görünümünü sürdürdüğü görülmektedir. Fakat ilgili sıralamada 2015 yılında 78'inci sıradan 2019'da 82'nci sıralamaya 
gerilediği tespit edilmiştir. "Turizm Politikaları ve Koşulların Etkinleştirilmesi" faktörünün ise 2015 yılında 85'inci sırada "orta" bir görünüm sergilerken 2019 yılında 56'ncı sırada "iyi" bir görünüme yükseldiği görülmektedir. "Altyapı" faktörüne ilişkin olarak ise 2015 yılında 39'uncu sırada "iyi" bir görünüme sahip olduğu 2019 yılında da 38inci sırada "iyi" görünümünü sürdürdüğü belirlenmiştir. Son olarak "Doğal ve Kültürel Kaynaklar" faktörüne ilişkin 2015 yılında 29'uncu sırada “çok iyi” bir görünüm sergilediği ve 2019 yılında 27'nci sırada bu görünümünü sürdürdüğü görülmektedir. 2015 ve 2019 TTCI verileri ana faktör gruplarına göre kıyaslamasında Türkiye'nin rekabet gücünün Turizm Politikaları ve Koşulların Etkinleştirilmesi faktöründe sıralamalarda en yüksek gelişim ivmesine sahip olduğu ve "orta" görünümden "iyi" görünüme yükseldiği saptanmıştır. Ayrıca Altyapı faktöründeki "iyi" görünümü ile Doğal ve Kültürel Kaynaklar faktöründeki "çok iyi" durumunu sürdürdüğü belirlenmiştir. Buna karşın Çevresel Faktörler' de ise "orta" görünümde ve ana faktörler içerisinde en düşük düzeyde görünüm sergilemeye devam etmiştir. Sıralamalara ilişkin diğer faktörlerde ilerlemeler kaydedilirken Çevresel Faktörler'de gerilemeler sergilediği tespit edilmiştir. Ayrıca Aydemir ve arkadaşlarının (2014) 2013 yılı TTCI raporu değerlendirmesine göre güvenlik, çevresel sürdürülebilirlik, karayolu ulaşımı ve sağlık-hijyen faktörleri bakımından sıralamada kötü durumda yer aldığı saptanmıştır. 2019 TTCI raporunda ise karayolu ulaşımı ve bağlantılarında "iyi" ve sağlık-hijyen faktöründe "orta" bir pozisyona yükselerek gelişim göstermesine rağmen çevresel sürdürülebilirlik ile emniyet ve güvenlik faktörlerinde "çok zayıf" bir pozisyondadır.

TTCI raporlarına ilişkin Tablo 6 ve yukarıdaki bilgiler ışığında Türkiye'de öncelikle güncel durumunu sergileyen 2017 ve 2019 yıllarına ait son iki dönemde sürekli düşüş ivmesi gösteren faktörler olan Çevresel Sürdürülebilirlik, İş Çevresi, İnsan Kaynakları ve İş Gücü Piyasası ile Sağlık ve Hijyen faktörlerine ilişkin mevcut strateji faaliyet alanlarının geliştirilmesi ve iyileştirmelerde bulunulması gerekmektedir. Araştırma kapsamında alanyazında elde edilen bilgilere göre bu faktörler içerisinde özellikle Sağlık ve Hijyen faktörünün tüm dünyayı etkisine alan Covid-19 salgınıyla birlikte Türkiye'de başlatılan ve diğer ülkelere de öncü olan başarılı uygulamalarının ışığında gelecek dönem raporlarında hızlı bir yükseliş ivmesi yakalayacağı söylenebilir (T. C. Kültür ve Turizm Bakanlığı, 2020). Bununla birlikte yine son iki dönemde hızlı veya kalıcı yükselişler kaydeden Turizmin Önceliklendirilmesi ve Fiyat Rekabet Gücü faktörleri genel sıralamadaki "iyi" görünümü korumada ve sürdürülebilirliğini sağlamada etken faktörlerdendir. Ayrıca bu iki faktöre ilişkin yükselişler turizmin gelişimini ve talep gücünü doğrudan ilgilendirdiğinden diğer faktörleri de zaman içerisinde olumlu yönde etkileyebilecektir.

Faktörler arası en iyi dereceye sahip ve "çok iyi" görünüm sergileyen Kültürel Kaynaklar ve İş Seyahati faktörüne yönelik 2019 yılında bir basamak gerileme görülmektedir. Aynı yıl belirgin düşüş sergileyen Doğal Kaynaklar faktörüne ilişkin atılacak adımlarla birlikte Kültürel Kaynaklar ve İş Seyahati faktörü de yükseliş gösterebilecektir. Bu bağlamda UNESCO Dünya Mirası Listesi'ndeki 18 miras alanı (16'sı kültürel ve 2'si karma) sayısına ilave olarak geçici listede yer alan kültürel alanlarla birlikte doğal alanların sayısını arttırmaya yönelik projelerin hayata geçirilmesi sağlanmalıdır. Bununla beraber UNESCO Yaratıcı Şehirler Ağı programında yer alan altı şehrimize ilave olarak yaratıcı şehirlerimizin sayısının arttırılması hususunda faaliyetler sürdürülmelidir. Ayrıca aynı faktöre bağlı olan potansiyel iş dünyası hareketliliğine ilişkin "Kongre ve Fuar Turizmi" nin zenginleştirilmesi gerekmektedir.

2019 yılında görünümü "iyi" bir rekabetçi pozisyonda olan ve bu durumunu sürdüren Kara Ulaşımı ve Bağlantıları, Uluslararası Açıklık ve Turistik Hizmet Altyapısı faktörlerinin yakalanan yükseliş ivmesini sürdürmesi ve ilerleyen dönemlerde belirlenen hedeflerin hayata geçirilmesiyle sıralamalarda yükseleceği söylenebilir. İstanbul'da "Galataport Limanı"nın 2021 yılında faaliyete geçmesi buna örnek verilebilir (GalataPort, 2021). Mevcut görünümü "çok iyi" 
olan Hava Taşımacılığı Altyapısı faktörünün 2019 yılı raporunda düşüş ivmesi belirgin olsa da mevcut yatırımların hayata geçmesiyle örneğin 2018 yılında İstanbul Hava Limanı'nın faaliyete girmesiyle birlikte hızlı bir yükseliş ivmesi yakalayacağını söylemek mümkündür (İstanbul Airport, 2018).

Bilişim Teknolojilerinde Hızlılık faktörüne ilişkin olarak TTCI 2019 raporunda "orta" görünüm sergileyen Türkiye'nin, son yıllarda bilişim ve teknoloji odaklı atılımlarılya ülke genelinde iletişim ağını etkin bir biçimde geliştirdiği ve gelecek raporlarda ortalamanın üzerinde bir görünüm sergileyebileceği söylenebilir. Bununla birlikte Türkiye, son zamanlarda turizmi de içine dahil eden iletişim teknolojileri odaklı sürdürülebilir etkin faaliyetler geliştirmektedir. Bu faaliyetlerden Turizm Teknolojilerini 2021 yılında yarışmalarına katan TeknoFest organizasyonu örnek olarak verilebilir (TEKNOFEST, 2021). Faktörlere yönelik bu örnek gelişmelerin yanında "çok zayıf" görünüm sergileyen Emniyet ve Güvenlik faktörüne ilişkin son yıllarda Türkiye'nin terörle mücadelede etkin başarısıyla yine gelecek raporlarda olumlu bir ivme göstereceğini söylemek mümkündür. Buna bağlı olarak özellikle Doğu ve Güneydoğu Anadolu Bölgelerinin turizme hızlı ve etkin bir biçimde kazandırılması; hedeflenen niş pazar çeşitliliğini zenginleştirecek, Türkiye turizminin ülke sathına tam yayılımını sağlayacak ve uluslararası raporlara ilişkin genel sıralamalarda önemli katkılar oluşturacaktır. Çalışma kapsamında Türkiye'nin mevcut rekabetçi gücünü koruması ve arttırması için "çok iyi, iyi ve orta" kategorilerde yer aldığ 1 tüm faktör ve göstergelerdeki konumunun daha etkin sürdürülmesinin yanında öncelikli olarak "zayıf ve çok zayıf" düzeyde olduğu faktör ve göstergelerde iyileştirici politikaların hayata hızla geçirilmesi önerilir.

$\mathrm{Bu}$ çalışmada Dünya Ekonomik Forumu (WEF) verileri kullanılmıştır. Ortaya çıkarılan bulguların geçerlik ve güvenirliğinin TTCI raporlarında yayınlanan verilerin geçerlik ve güvenirliğine bağlı olması araştırma sınırlılığını teşkil etmektedir. Ayrıca gelecek dönem raporlarının da benzer yaklaşımlarla incelenmesi Türkiye'nin rekabet gücünü etkileyen faktörlere ilişkin mevcut durumu belirlemede fayda sağlayacaktır.

\section{KAYNAKÇA}

Akkuş, G. (2018). Türkiye'nin Destinasyon Rekabetçiliği Puanları İle Temel Makroekonomik Göstergeler ve Turizm Verileri Arasındaki İlişkinin Değerlendirilmesi. Uluslararası Kültür ve Bilim Kongresi, Ankara Kongre Merkezi, Ankara. 3-5 Mayıs 2018. ss: 643-654.

Alaeddinoğlu, F. ve Rol, S. (2020). Covid-19 Pandemisi ve Turizm Üzerindeki Etkileri. Yüzüncü Yal Üniversitesi Sosyal Bilimler Enstitüsü Dergisi, 233-258.

Ankomah, P. K., Crompton, J. L. and Baker, D. (1996). Influence of Cognitive Distance in Vacation Choice. Annals of Tourism Research, 23(1), 138-150.

Armenski, T., Gomezelj, O., Djurdjev, B., Deri, L. and Dragin, A. (2011). Destination Competitiveness: A Challenging Process for Serbia. Human Geographies, 5(1), 19-33.

Aydemir, B., Saylan, U. ve Aydoğmuş, F. (2014). Turizmde Rekabet: Seyahat ve Turizm (T\&T) Rekabet Edebilirlik Raporunda Türkiye'nin ve Avrupa'nın Değerlendirilmesi. Çukurova Üniversitesi İIBF Dergisi, 18(1), 1-15.

Aytaç, A. (2016). Dünya Girişimcilik Vizelerini Benimsedi. Peki, Biz Hala Neyi Bekliyoruz? Ankara: TEPAV. [Online] https://www.tepav.org.tr/upload/files/14537302733.Dunya_Girisimcilik_Vizelerini_Benimsedi._Peki_Biz_Hala_Neyi_Bekliyoruz.pdf [Erişim Tarihi: 10.01.2021]. 
Bahar, O. ve Çelik, İ. N. (2020). Coronavirüsün (Covid-19) turizm sektörü üzerindeki ekonomik etkileri. International Journal of Social Sciences and Education Research, 6(1), 125-139.

Bahar, O. ve Kozak, M. (2005). Türkiye Turizminin Akdeniz Ülkeleri ile Rekabet Gücü Açısından Karşılaştırılması. Anatolia: Turizm Araştırmaları Dergisi, 16(2), 139-152.

Bãlan, D., Balaure, V. and Veghes, C. (2009). Travel and Tourism Competitiveness of the World's Top Destinations: An Exploratory Assessment. Annales Universitatis Apulensis Oeconomica, 11(2), 979-987.

Baloglu, S. and McCleary, K. W. (1999). U.S. International Pleasure Travelers' Image of Four Mediterranean Destinations: A Comparison of Visitors and Non-Visitors. Journal of Travel Research, 38, 144-152.

Batuhan, T. (2020). On Birinci Kalkınma Planında Turizm Politikaları. Uluslararası Global Turizm Araştırmaları Dergisi, 4(2), 77-84.

Bello, Y. O., Bello, M. B. and Rana, N. R. (2014). Travel and Tourism Business Confidence Index in Nigeria: Issues and Challenges. Afrikan Journal of Hospitality, Tourism and Leisure, 3(2), 1-15.

Buhalis, D. (2000). Marketing the Competitive Destination of the Future. Tourism Management, 21(1), 97-116.

Burnaz, E. ve Ayyıldız, H. (2018). Destinasyon Rekabetçiliği Endeksi Önerisi. Uluslararası İktisadi ve İdari İncelemeler Dergisi, 21, 237-254.

Bülbül, D. (2012). Türkiye'de Turizm Sektörünün Vergi Yükü ve Turizm Sektörünün Vergilendirilmesine Yönelik Öneriler. Vergi Dünyası 365, 158-165.

Chako, H. (1997). Positioning a Destination to Gain Competitive Edge. Asia Pasific Journal of Tourism Research, 1(2), 69-75.

Cracolici, M. F. and Nijkamp, P. (2008). The Attractiveness and Competitiveness of Tourist Destinations: A Study of Southern Italian Regions. Tourism Management, 30(3), 336-344.

Croitoru, M. (2011). Tourism Competitiveness Index-an Empirical Analysis Romania vs. Bulgaria. Theoretical \& Applied Economics, 18(9), 155-172.

Crouch, G. I. (2007). Measuring Tourism Competitiveness: Research, Theory and the WEF Index. Australia \& New Zealand Marketing Academy Conference (ANZMAC) (s. 73-79). 3-5 Aralık: Dunedin New Zealand.

Crouch, G. I. (2011). Destination Competitiveness: An Analysis of Determinant Attributes. Journal of Travel Research, 50(1), 27-45.

Crouch, G. I. and Ritchie, J. R. (1999). Tourism, Competitiveness, and Societal Prosperity. Journal of Business Research, 44(3), 137-152.

Çağlıyan, V. ve Göral, R. (2017). Uluslararası Turizm Rekabetçiliği ve Turizmin Ekonomik Etkisi Üzerine Bir Değerlendirme. TURAN Stratejik Araştırmalar Merkezi Dergisi, 9(33), 45-53.

Çakır, P. ve Barakazı, M. (2020). Koranavirüs Sürecinin Turizm Sektörüne Etkisi ve Salgına Karşı Alınan Tedbirler. Anadolu Üniversitesi Sosyal Bilimler Dergisi, 20(3), 313-332.

Çivi, E., Erol, İ., İnanlı, T. ve Erol, E. D. (2008). Uluslararası Rekabet Gücüne Farklı Bakışlar. Ekonomik ve Sosyal Araştırmalar Dergisi, 4(4), 1-22. 
Dalkıran, G. B. ve Bayrak, Ö. A. (2020). Pandemi Dönemi Turizmde Rusya Pazarı ve Türkiye'ye Yönelik Seyahat Planlarında Sağlık Turizmi Boyutu. Balkan ve Yakın Doğu Sosyal Bilimler Dergisi, 6, 221-228.

Das, J. and Dirienzo, C. E. (2012). Tourism Competitiveness and the Role of Fractionalization. International Journal of Tourism Research, 14, 285-297.

Demir, İ. (2020). En Uzun Kim Yaşamalı? Sağlık, Sağlık Hizmetleri ve Sağlık Politikası. Ekonomi Politikaları, 109-133.

DHMI. (2019). Devlet Hava Meydanları İşletmesi Genel Müdürlüğü 2019 Raporu. Faaliyet Raporu. [Online] https://www.dhmi.gov.tr/Sayfalar/FaaliyetRaporlari.aspx [Erişim Tarihi: 10.04.2021].

Dias, J. G. (2017). Environmental Sustainability Measurement in the Travel \& Tourism Competitiveness Index: An Empirical Analysis of its Reliability. Ecological Indicators, 73, 589-596.

Doğan, M. (2015). Avrupa Birliği ve Türkiye Ekonomik İlişkileri. Marmara Coğrafya Dergisi(32), 306-325.

Dupeyras, A. and MacCallum, N. (2013). Indicators for Measuring Compettiveness in Tourism: A Guidance Document. OECD Tourism Papers. February 2013: OECD Publishing.

Dünya Bankası. (2019). Doing Business 2020. Dünya Bankası. [Online] https://www.doingbusiness.org/en/reports/global-reports/doing-business-2020 [Erişim Tarihi: 12.01.2021].

Dwyer, K. and Kim, C. (2003). Destination Competitivenes: Determinants and Indicators. Current Issues In Tourism, 6(5), 369-414.

Dwyer, L., Forsyth, P. and Rao, P. (2000). The Price Competitiveness of Travel and Tourism: A Comparison of 19 Destinations. Tourism Management, 21(1), 9-22.

Enright, M. J. and Newton, J. (2004). Tourism Destination Competitiveness: A Quantitative Approach. Tourism Management, 25(6), 777-788.

Enright, M. J. and Newton, J. (2005). Determinants of Tourism Destination Competitiveness in Asia Pacific: Comprehensiveness and Universality. Journal of Travel Research, 43(1), 339-350.

Fedajev, A., Popovic, G. and Stanujkic, D. (2019). MCDM Framework for Evaluation of the Tourism Destination Competitiveness. In Proc. of 5thInternational Scientific Conference Innovation as an Initiator of the Development, MEFkon 2019. Belgrade, Serbia. December 5th, ss: 112-119.

Forsyth, P. and Dwyer, L. (2009). Tourism Price Competitiveness, The Travel and Tourism Competitiveness Report 2009. Switzerland: World Economic Forum Geneva.

GalataPort. (2021). GalataPort. GalataPort Hakkında. [Online] https://www.galataport.com/tr/hakkinda [Erişim Tarihi: 30.03.2021].

Göral, R. (2016). Turizm Destinasyonu Rekabetçilik Faktörleri ve ENTROPİ Yöntemiyle Ağırlıklandırması. Ekonomi ve Yönetim Araştırmaları Dergisi, 5(2), 66-81.

Göral, R. (2017). Dünya Ekonomik Forumu Turizm Rekabetçilik Raporu Işı̆̆ında Türkiye Turizminin Rekabetçilik Sorunları. Akademik Bakış Dergisi(61), 141-166.

Gursoy, D. and Kendall, K. W. (2004). A Competitive Positioning of Mediterranean Destinations. In Proceedings of EuroChrie Congress. Ankara, Turkey. 
Güllü, K. and Yılmaz, M. (2020). Determination of Destination Competitiveness of The Selected Mediterranean Destinations by ENTROPY Based EDAS Method. Erciyes Üniversitesi Sosyal Bilimler Enstitüsü Dergisi, 48, 486-509.

Gündüzöz, İ. (2010). İşyeri Açma ve Çalışma Ruhsatı. Ankara: Türkiye Belediyeler Birliği.

Hassan, A. ve Uşaklı, A. (2013). Seyahat ve Turizm Rekabetçilik Endeksi: Akdeniz Çanağındaki Destinasyonlara Yönelik Karşılaştırmalı Bir Analiz. Seyahat ve Otel İşletmeciliği Dergisi, 10(2), 5367.

Hassan, S. (2000). Determinants of Market Competitiveness in an Environmentally Sustainable Tourism. Journal of Travel Research, 38(February), 239-245.

Heath, E. and Wall, G. (1992). Marketing Tourism Destinations: A Strategic Planning Approach. New York: John Wiley \& Sons Inc.

Hovinen, G. (2002). Revising The Destination Life Cycle Model. Annals of Tourism Research, 29(1), 209-230.

Huang, J. H. and Peng, K. H. (2012). Fuzzy Rasch Model in TOPSIS: A New Approach for Generating Fuzzy Numbers to Assess the Competitiveness of the Tourism Industries in Asian Countries. Tourism Management, 33, 456-465.

Huybers, T. and Bennett, J. (2003). Environmental Management and the Competitiveness of Nature-Based Tourism Destinations. Environmental and Resource Economics, 24(3), 213-233.

ICCA. (2019). ICCA 2018 Kongre Turizmi Raporu, TUROB. [Online] http://www.turob.com/Files/Dosyalar/pdf/ICCA\%202018\%20Statistics_Public\%20Abstract.pdf [Erişim Tarihi: 02.02.2021].

Ilinčić, M. and Pavlović, S. (2017). Assessment of Tourism Development in Serbia Using the Travel and Tourism Competitiveness Index (TTCI). ББК 65.43 И 60, (s. 53-55).

İstanbul Airport. (2018). İstanbul Havalimanı. [Online] https://www.istairport.com/tr [Erişim Tarihi: 30.03.2021].

Jamal, T. B. and Getz, D. (1996). Does strategic planning pay? Lessons for Destinations from Corporate Planning Experience. Progress in Tourism and Hospitality Research, 2(1), 59-78.

Karadağ, S. and Bağcı, E. (2019). Döviz Kurundaki Yükselmenin Turizm Sektörüne Etkisi: 20102018 Arası Türkiye Örneği. Akademik Sosyal Araştırmalar Dergisi(100), 439-457.

Kayar, Ç. H. and Kozak, N. (2010). Measuring Destination Competitiveness: An Application of the Travel and Tourism Competitiveness Index (2007). Journal of Hospitality Marketing \& Management, 19(3), 203-216.

Kim, S. S., Chon, K. and Chung, K. Y. (2003). Convention Industry in South Korea: An Economic Impact Analysis. Tourism Management, 24(5), 533-541.

KMPG Türkiye. (2021). Turizm Sektörünün Mali Gündemi ve Sürdürülebilirlik. [Online] https://assets.kpmg/content/dam/kpmg/tr/pdf/2021/03/turizm-sektorunun-mali-gundemisurdurulebilirlik-2021.pdf [Erişim Tarihi: 14.04.2021].

Kozak, M. (2002). Measuring Comparative Destination Performance: A study in Spain and Turkey. Journal of Travel \& Tourism Marketing, 13(3), 83-110.

Kozak, M. and Rimmington, M. (1999). Measuring Tourist Destination Competitiveness: Conceptual Considerations and Empirical Findings. International Journal of Hospitality Management, 18(3), 273-283. 
Manap Davras, G. (2020). Akdeniz Turizm Destinasyonlarının Rekabet Gücü Açısından TOPSIS ve VIKOR Yöntemleri ile Karşılaştırılması. Journal of Tourism and Gastronomy Studies, 8(2), 14391456.

Marti, L. and Puertas, R. (2017). Determinants of Tourist Arrivals in European Mediterrian Countries: Analysis of Competitiveness. European Journal of Tourism Research, 15, 131-142.

Okur, M. A. (2020). Covid-19 Salgını, Dünya Düzeni ve Türkiye. Akademik Hassasiyetler, 7(13), 311335.

Omerzel, D. G. (2006). Competitiveness of Solvenia as a Tourist Destination. Managing Global Transitions, 4(2), 167-189.

Özhavzalı, M. ve Erduran, T. (2019). Bilgi İletişim Teknolojilerinin Gelişimine Göre Büro Yönetimi Ve Yönetici Asistanlığı Programının Bir Analizi. Ekonomi İşletme Siyaset ve Uluslararası İlişkiler Dergisi, 5(2), 144-155.

Papatheodorou, A. (2002). Exploring Competitiveness in Mediterranean Resorts. Tourism Economics, 8, 133-150.

Pata, U. K. (2020). Turizm, Finansal Gelişme, Ticari Açıklık Ve Sermaye Stokunun Ekonomik Büyüme Üzerindeki Etkileri: Türkiye Örneği. Ç.Ü. Sosyal Bilimler Enstitüsü Dergisi,, 29(4), 151167.

Patsouratis, V., Frangouli, Z. and Anastasopoulos, G. (2005). Competition in Tourism among the Mediterranean Countries. Applied Economics, 37(16), 1865-1870.

Peng, K. H. and Tzeng, G. H. (2012). Strategies for Promoting Tourism Competitiveness Using a Hybrid MCDM Model. In Intelligent Decision Technologies (s. 107-115). içinde Berlin, Heidelberg: Springer.

Pike, S. and Page, S. (2014). Destination Marketing Organizations and Destination Marketing: A Narrative Analysis of the Literature. Tourism Management(4), 202-227.

Ritchie, J. B. and Crouch, G. I. (2003). The Competitive Destination: A Sustainable Tourism Perspective. USA: CABI Publishing.

Sarı, V. İ. (2019). Türkiye'de Ulusal ve Bölgesel Politika Belgelerinde Sürdürülebilir Turizm Planlaması. Coğrafi Bilimler Dergisi, 18(1), 1-27.

Seven, E. (2020). Türkiye'nin Biyoçeşitlilik Turizm Potansiyeli Üzerine Bir Değerlendirme. Journal of Current Debates in Social Sciences, 3(2), 95-103.

Sönmez, R. ve Eroğlu, U. (2021). Havayolu Sektöründe Rekabetçi Hamlelerin Belirlenmesi: Sektöre Özgü Bir Tipoloji Önerisi. Ege Stratejik Araştırmalar Dergisi, 12(1), 52-69.

T.C. Çevre ve Şehircilik Bakanlığı. (2017). Çevresel Göstergeler. [Online] https://cevreselgostergeler.csb.gov.tr/korunan-alanlar-i-

85778\#: :text=De\%C4\%9Ferlendirme\%3A,\%258\%2C9'dur. [Erişim Tarihi: 02.02.2021].

T.C. Gençlik ve Spor Bakanlı̆̆ı. (2021). Yeni Adana Stadyumu Açıldı. [Online] https://gsb.gov.tr/HaberDetaylari/1/1/225226/yeni-adana-stadyumu-acildi.aspx [Erişim Tarihi: 15.04.2021].

T.C. Kalkınma Bakanlığı. (2018a). Turizm Onbirinci Kalkınma Planı (2019-2023). Ankara. [Online] https://sbb.gov.tr/wp-content/uploads/2020/04/TurizmOzellhtisasKomisyonuRaporu.pdf [Erişim Tarihi: 14.04.2021]. 
T.C. Kalkınma Bakanlığı. (2018b). Bilgi ve İletişim Teknolojileri Onbirinci Kalkınma Planı (2019-2023). Ankara: [Online] https://sbb.gov.tr/wpcontent/uploads/2020/04/Bilgi_ve_IletisimTeknolojileriOzellhtisasKomisyonuRaporu.pdf [Erişim Tarihi: 15.04.2021].

T.C. Kültür ve Turizm Bakanlığı. (2018). 3. Turizm Şurası Şura Kitabı. Ankara.

T. C. Kültür ve Turizm Bakanlığı. (2020). "Güvenli Turizm Programı" Turizmde olumlu Sonuç Verdi. Basın ve Halkla İlişkiler Müşavirliği. [Online] https://basin.ktb.gov.tr/TR-274226/guvenli-turizmprogrami-turizmde-olumlu-sonuclar-verdi.html [Erişim Tarihi: 31.03.2021].

T.C. Kültür ve Turizm Bakanlığı. (2021). Aralık 2020 Sınır Bülteni. Turizm İstatistikleri. [Online] https://yigm.ktb.gov.tr/TR-9851/turizm-istatistikleri.html [Erişim Tarihi: 22.02.2021].

T.C. Ulaştırma ve Altyapı Bakanlığı. (2020). Ulaşan ve Erişen Türkiye 2020. [Online] https://www.uab.gov.tr/bakanlik-yayinlari?PageSpeed=noscript [Erişim Tarihi: 15.04.2021].

TEKNOFEST. (2021). Turizm Teknolojileri Yarışması. TEKNOFEST [Online] https://teknofest.org/yarisma-detaylar-42.html [Erişim Tarihi: 30.03.2021].

TEPAV. (2019). Türkiye'ye Gelen Ve Türkiye'den Giden Doğrudan Yatırımlardaki Gelişmeler. [Online] https://www.tepav.org.tr/upload/files/1566298453-

3.Turkiye__ye_Gelen_Ve_Turkiye__den_Giden_Dogrudan_Yatirimlardaki_Gelismeler__Ag ustos_2019.pdf [Erişim Tarihi: 15.04.2021].

Tezcan, K., Karadeniz, E., Kandır, S. Y. ve Önal, Y. B. (2008). Türk Turizm sektörünün Gelişimi Açısından Uygulanan Vergi politikalarının Değerlendirilmesi. IV. Lisansüstü Turizm Öğrencileri Araştırma Kongresi, 23-27 Nisan 2008. Belek/Antalya. ss: 827-851.

Turizm Güncel. (2020). Kültür ve Turizm Bakanlığı'nın 2021 yılı bütçesi ne kadar? [Online] https://www.turizmguncel.com/haber/kultur-ve-turizm-bakanliginin-2021-yili-butcesi-ne-kadar [Erişim Tarihi: 02.02.2021].

Turizm Günlügü. (2020). Turizmde yeni KDV oranları. [Online] https://www.turizmgunlugu.com/2020/08/08/turizmde-yeni-kdv-oranlari/ [Erişim Tarihi: 15.03.2021].

Türkiye Bilişim Derneği. (2020). TBD Küresel Gelişmeler Raporu 2020. [Online] https://www.tbd.org.tr/pdf/tbd-kuresel-gelismeler-raporu-2020.pdf [Erişim Tarihi: 03.04.2021].

UNESCO. (2020). UNESCO Türkiye Millı̂ Komisyonu. [Online] https://www.unesco.org.tr/Pages/125/122/UNESCO-D\%C3\%BCnya-Miras\%C4\%B1-Listesi [Erişim Tarihi: 02.02.2021].

UNWTO. (2020). UNWTO World Tourism Barometer and Statistical Annex, January 2020. 01 31, UNWTO $\quad$ elibrary. [Online] https://www.eunwto.org/doi/epdf/10.18111/wtobarometereng.2020.18.1.1 [Erişim Tarihi: 31.01.2021].

UNWTO. (2021). UNWTO World Tourism Barometer and Statistical Annex, January 2021. UNWTO elibrary. [Online] https://www.e-unwto.org/doi/abs/10.18111/wtobarometereng.2021.19.1.1 [Erişim Tarihi: 31.01.2021].

Webster, C. and Ivanov, S. (2014). Transforming Competitiveness into Economic Benefits: Does Tourism Stimulate Economic Growth in More Competitive Destinations? Tourism Management, 40, 137-140. 
WEF. (2015). Travel and Tourism Competitiveness Report 2015. World Economic Forum. [Online] https://www.weforum.org/reports/travel-and-tourism-competitiveness-report-2015 [Erişim Tarihi: 03.04.2021].

WEF. (2017). The Travel \& Tourism Competitiveness Report 2017. World Ecomoic Forum. [Online] https://www.weforum.org/reports/the-travel-tourism-competitiveness-report-2017 [Erişim Tarihi: 04.04.2021].

WEF. (2019). The Travel \& Tourism Competitiveness Report 2019. World Economic Forum. [Online] http://www3.weforum.org/docs/WEF_TTCR_2019.pdf [Erişim Tarihi: 01.02.2021].

WTTC. (2020). Economic Impact Reports. 04 15, 2021 tarihinde World Travel Tourism Council. [Online] https://wttc.org/Research/EconomicImpact/moduleId/704/itemId/224/controller/DownloadRequest/action/QuickDownload [Erişim Tarihi: 15.04.2021]. 